\title{
AÇIK MADEN İŞLETMELERİNDE PARTİKÜL MADDE SALINIMI: LİTERATÜR ARAŞTIRMASI
}

\author{
Zekeriya DURAN $1^{*}$, Bülent ERDEM², Tuğba DOĞAN ${ }^{3}$ \\ ${ }^{1}$ Sivas Cumhuriyet Üniversitesi, Sivas Teknik Bilimler MYO, Madencilik ve Maden Çıkarma Bölümü, Sivas, \\ ORCID No : https://orcid.org/0000-0002-9327-8567 \\ 2 Sivas Cumhuriyet Üniversitesi, Mühendislik Fakültesi, Maden Mühendisliği Bölümü, Sivas, \\ ORCID No : https://orcid.org/0000-0002-1226-9248 \\ 3 Sivas Cumhuriyet Üniversitesi, Mühendislik Fakültesi, Endüstri Mühendisliği Bölümü, Sivas, \\ ORCID No : https://orcid.org/0000-0002-2628-4238
}

\begin{tabular}{|c|c|c|}
\hline Anahtar Kelimeler & & Öz \\
\hline $\begin{array}{l}P M_{1}, P M_{2,5}, P M_{10}, \\
\text { Toplam asklda } \\
\text { madde. }\end{array}$ & partikül & $\begin{array}{l}\text { Partikül madde (PM) kaynaklı hava kirliliği insan sağlığına ve çevreye zarar } \\
\text { verebilmektedir. Partikül madde kaynaklarından birisi de madencilik sektörüdür. Açık } \\
\text { maden işletmelerinde, yapılan faaliyet türüne (delme, patlatma, yükleme, taşıma, } \\
\text { slyırma, kırma, eleme vb.) bağlı olarak çalışma bölgelerinde değişik düzeylerde PM } \\
\text { salınımı oluşmaktadır. Bu nedenle sürdürülen her faaliyetin partikül madde salınım } \\
\text { değerlerinin ölçülmesi, bunların ilgili mevzuatta belirtilmiş olan sınır değerler dikkate } \\
\text { alınarak değerlendirilmesi ve olumsuz etkileri önleyici/azaltıcı önlemlerin planlanması } \\
\text { önemlidir. Konu üzerine yapılmış olan çalışmalar incelendiğinde, maden işletmelerinde } \\
\text { yapılan faaliyetin türüne göre oluşabilecek PM salınımını modelleyen denklemlerin } \\
\text { geliştirildiği ancak bunların, farklı işletmelerdeki aynı faaliyet için bile değiștiği tespit } \\
\text { edilmiştir. Bu nedenle, PM salınım değerlerinin maden işletmesine özgü olduğu, sürekli } \\
\text { salınım ölçümü yapmanın daha doğru sonuçlara ulaşılmasını sağlayacağı ve dolayıslyla } \\
\text { en gerçekçi yaklaşım olarak, bir maden işletmesinde sürdürülen her faaliyet için ayrı PM } \\
\text { salınım modellemesinin yapılmasının gerektiği sonucuna varılmıștır. }\end{array}$ \\
\hline
\end{tabular}

\section{PARTICULATE MATTER EMISSIONS in SURFACE MINING OPERATIONS: LITERATURE RESEARCH}

\begin{tabular}{l} 
Keywords \\
\hline$P M_{1}, P M_{2,5}, P M_{10}$ \\
Total suspended particulate \\
matter.
\end{tabular}

Abstract

Pollution due to particulate matter can harm human health and the environment. One of the particulate matter sources is the mining industry. Depending on the type of activity (drilling, blasting, loading, hauling, dozing, crushing, screening, etc.), various levels of PM emission occurs in surface mining operations. For this reason, it is important to measure the PM emission values of each ongoing activity, evaluate them by taking into consideration the limit values specified in the relevant legislation and to plan preventive/mitigating measures. When the studies conducted on the subject were examined, it was found out that the equations modeling the PM emission, which may occur according to the type of activity carried out in surface mines, were developed but they varied even for the same activity among different mines. For this reason, it was concluded that PM emission values are specific to the surface mines, that continuous emission measurement will provide more accurate results, and therefore, as the most realistic approach, separate PM emission modeling should be done for each activity carried out in a surface mine.

\begin{tabular}{llll}
\hline Derleme Makalesi & Review Article & \\
Başvuru Tarihi & $: 17.06 .2021$ & Submission Date & $: 17.06 .2021$ \\
Kabul Tarihi & $: 05.10 .2021$ & Accepted Date & $: 05.10 .2021$ \\
\hline
\end{tabular}

*Sorumlu yazar; e-posta : zduran@cumhuriyet.edu.tr

Bu eser, Creative Commons Attribution License (http://creativecommons.org/licenses/by/4.0/) hükümlerine göre açık erişimli bir makaledir.

This is an open access article under the terms of the Creative Commons Attribution License (http://creativecommons.org/licenses/by/4.0/). 


\section{Giriş}

Günümüzde hava kirliliği insan sağlı̆̆ için en önemli çevresel risklerden birisi haline gelmiştir. Dünya genelinde her yıl yaklaşık yedi milyon insan hava kirliliği sonucu meydana gelen hastalıklardan dolayı ölmekte ve on kişiden dokuzunun yüksek düzeyde kirletici içeren hava soluduğu belirtilmektedir (Air Pollution, 2020). Ülkemizde ise 2017 yllında hava kirliliği sonucu ölümlerin trafik kazalarından yedi kat daha fazla olduğu ve Dünya Sağlık Örgütünün 2013 yılında hava kirliliğine neden olan Partikül Maddeleri (PM) kanserojen ilan ettiği ifade edilmiştir (THHP, 2019). PM'ler hava kirliliğine neden olan önemli bileşenlerdendir (Kim, Kabir ve Kabir, 2015; Beloconi, Chrysoulakisc, Lyapustind, Utzinger ve Vounatsou, 2018; THHP, 2019). Açık ocak madenciliğindeki temel kirleticilerden birisi PM'lerdir. Dolayısıyla hava kalitesinin bozulmasında madencilik sektörünün katkısı önemsenmeyecek düzeyde büyüktür (Evyapan, Mungan, Akgün ve Arbak, 2012; Zhang, Chen, Ma ve Zhan, 2013; Pandey, Agrawal ve Singh, 2014; Patra, Guatam ve Kumar, 2016; THHP, 2019). Avrupa'da PM kaynakları bakımından madencilik sektörü $10 \mu \mathrm{m}$ 'den daha ince partikül için $\left(\mathrm{PM}_{10}\right)$ üçüncü sırada, 2,5 $\mu$ m'den daha ince partikül $\left(\mathrm{PM}_{2,5}\right)$ için dördüncü sırada yer almaktadır (Evyapan ve diğ., 2012). Bu yüzden, madencilik sektöründe çalışanlar hava kirliliğine bağlı toz ve partikül maddelerin (PM) zararlı etkilerine oldukça yüksek düzeyde maruz kalmaktadırlar.

Bu çalışmada araştırma ve yayın etiğine uyulmuştur.

\section{Partikül Madde}

Genellikle "toz", belirli bir süre boyunca havada askıda kalabilen $75 \mu \mathrm{m}$ 'nin altındaki partiküller için kullanılmaktadır (WHO, 1999). Ayrıca tozlar, çeșitli inorganik ve organik maddelerden; delme, kırma, taşınma, aşınma, öğütme, parçalanma ve yanma gibi olaylar sonucu oluşan, tane boyut aralıkları $1 \mu \mathrm{m}$ ile 100 $\mu \mathrm{m}$ arasında değișebilen ve yerçekiminin etkisiyle yavaş yavaş çöken maddelerdir (WHO, 1999; Vidinli ve diğ., 2016). PM ise hava içinde askıda bulunan katı ve sıvı partiküller (aerosoller) olarak tanımlanmaktadır. Partikül madde, nitratlar, sülfatlar, organik kimyasallar, metaller, toprak veya toz parçacıkları ve alerjenler (polen veya küf sporları gibi) gibi çeşitli bileșenlerden oluşabilir. Solunabilir partikül maddelerin esas kaynakları şantiyeler, fabrikalar, asfaltsız yollar, bacalar, enerji üretim tesisleri, madencilik, çimento fabrikaları ve yangınlardır (Rodriguez, Querol, Alastuey ve Rosa, 2007; Perrino, 2010; Şahin, 2012; THHP, 2019). Ayrıca, havada asılı halde bulunan PM türleri ve özellikleri; meydana geldikleri kaynak türüne, oluşum biçimine, tane boyut aralıklarına, dağılımlarına, özgül ağırlıklarına, içeriklerindeki özel bileşenlere ve yayılım gösterdikleri veya bulundukları ortama bağlı olarak değişebilmektedir (Şahin, 2012).

Atmosferik boyut dağılımlarının temel formu Whitby, Husar ve Liu (1972) tarafından tanımlanmış ve Liu, Whitby ve Pui (1974) daha sonra geliştirilmiş halini oluşturmuştur (Şekil 1). Bu araştırmacılar başlangıçta tipik partikül büyüklüğü dağılımlarının, birbirleriyle örtüşen iki log-normal eğri ile en az $1 \mu \mathrm{m}$ ila $3 \mu \mathrm{m}$ bölgesinde açıklanabileceği sonucuna varmışlardır (Cao, Chow, Lee ve Watson, 2013). Buna göre; aerodinamik çapı 0,01 $\mu$ m'den küçük PM'ler çok çok ince (nano), 0,01 $\mu \mathrm{m}$ ile 0,1 $\mu \mathrm{m}$ arasındaki partiküller çok ince (ultra), $\sim 0,1 \mu \mathrm{m}$ ile $\sim 2,0 \mu \mathrm{m}$ arasındaki partiküller ince, $\sim 0,2 \mu \mathrm{m}$ yoğunlaşma, $\sim 0,7 \mu \mathrm{m}$ damlacık oluşumu, $\sim 2 \mu \mathrm{m} \sim 3 \mu \mathrm{m}$ ile $100 \mu \mathrm{m}$ arasındaki PM'ler kaba (coarse) ve toplam askıda partikül madde (TAPM) 0 ile $\sim 30 \mu \mathrm{m}-50 \mu \mathrm{m}$ arasındaki partiküller olarak tanımlanmaktadır (Cao ve diğ., 2013). Diğer taraftan çapları $30 \mu$ m'ye kadar olan partiküller TAPM, çapları $2,5 \mu \mathrm{m}-10 \mu \mathrm{m}$ arasında olanlar kaba partiküller, çapları $\leq 2,5 \mu \mathrm{m}$ altında olan partiküller ince ve çapları $\leq 0,1 \mu \mathrm{m}$ olan partiküller ultra ince ya da ultrafine (UF) partiküller olarak isimlendirilebilir (Evyapan ve diğ., 2012).

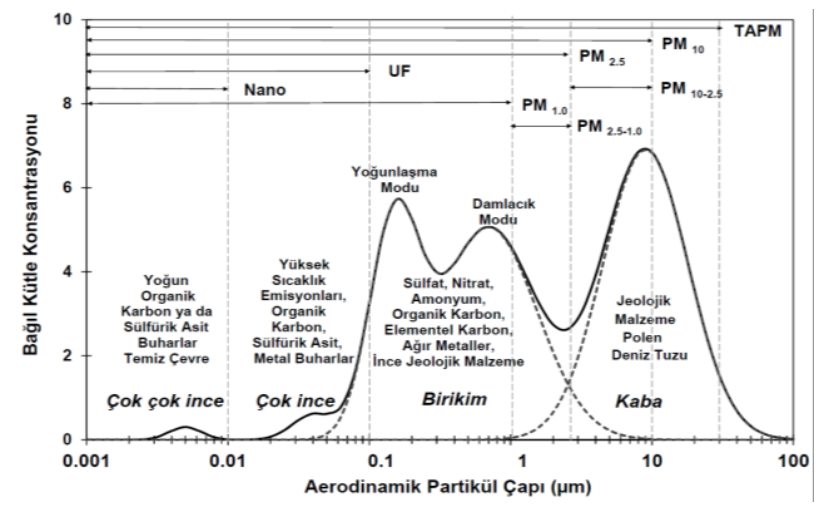

Şekil 1. Partikül Boyut Dağılımı (Cao ve diğ., 2013)

PM’lerin büyüklüğü, insanlarda sağlık sorunlarına neden olma potansiyeli ile doğrudan bağlantılı olduğu için PM çapı insan sağlığı için son derece önemlidir. 30 $\mu \mathrm{m}$ ve altı partiküller toplam askıda partikül madde (TAPM) olarak bilinmektedir. $10 \mu \mathrm{m}-30 \mu \mathrm{m}$ arası boyuttaki partiküller havada sınırlı bir süre için askıda kalmaktadırlar. Bu boyut aralığındaki PM'ler burun delikleri veya ağızda tutularak yutuldukları için sağlık açısından endişe oluşturmamaktadır. $10 \mu \mathrm{m}$ 'den daha ince partiküllerin ( $\left.\mathrm{PM}_{10}\right)$ solunum yolu ile alınması daha olasıdır. 2,5 $\mu$ m'den küçük partiküller $\left(\mathrm{PM}_{2,5}\right)$ ile 1 $\mu \mathrm{m}$ 'den daha ince partiküller $\left(\mathrm{PM}_{1}\right)$ solunum yolu ile akciğerlere kadar ulaşabilirler. Bu yüzden $\mathrm{PM}_{10}, \mathrm{PM}_{2,5}$ ve $\mathrm{PM}_{1}$ insan sağlı̆̆ üzerinde olumsuz etkilere sahip olan partikül boyutlar olup insan sağlığı için $10 \mu \mathrm{m}$ 'den daha küçük partiküllerin $\left(\mathrm{PM}_{10}\right)$ ortamdaki yoğunluğu 
ölçülmelidir (Tsiouri, Kakosimos ve Kumar, 2015; Patra ve diğ., 2016; Health Effects, 2020). Ayrıca, 5 mm'den büyük partiküllerin üst solunum yolunda tutulduğu, 1 $\mu \mathrm{m}$ veya daha küçük boyuttaki partiküllerin ise alveollere ulaştığı ifade edilmiştir (Badu, 2014). Amerika Birleşik Devletleri Çevre Koruma Ajansı (USEPA), çapı 10 mikrondan daha küçük olan partiküllerin insan sağlığı için büyük problem oluşturduğunu, bu çaptaki PM'lerin akciğerlerin derinlerine inebildiğini, kan dolaşımına girebildiğini, akciğerleri ve kalbi etkileyebildiğini belirtmiştir. $\mathrm{PM}_{2,5}$ insan sağlığı için en büyük riski oluşturmaktadır (Evyapan ve diğ., 2012; Xing, Xu, Shi ve Lian, 2016; Martins ve Carrilho da Graça, 2018; Gao ve diğ., 2018; Miller ve Xu, 2018; THHP, 2019; PM, 2020).

Partikül kirliğine maruz kalınması sonucu insanlarda kalp (ölümcül olmayan kalp krizi, düzensiz kalp atışı) ve akciğer (ağır astım, akciğer fonksiyonunda azalma, solunum yollarında tahriş, öksürme veya nefes alma zorluğu gibi artan solunum belirtileri) gibi değişik hastalıklara yakalanma olasılığı bulunmaktadır. Çocuklar ve yaşlılar, partikül madde maruziyetinden etkilenme olasılığı en yüksek bireyler olarak tanımlanmaktadır (CAFE, 2004; WHO, 2006; Choudhary ve Garg 2013; NSW EPA, 2015; Kim ve diğ., 2015; THHP, 2019). Hava kirliliğine katkıda bulunan temel bileşenlerden birisi olan PM'ler insanların görüş alanını azaltılabileceği ve bunun nemli havada daha belirgin olduğu ifade edilmektedir. İnsanların görüşünü azaltan en önemli PM boyutu PM2,5 (NSW EPA, 2015) ve çapları 0,3 - 0,6 mikron arası olanlardır (ÇEDB, 2004).

Epidemiyolojik ve deneysel çalışmalar sonucunda PM'lerin eşit derecede toksik olmadığı ve sağlık için farklı riskler taşıdığı belirtilmektedir. İnsan vücudundaki solunum sistemine, akciğerlere ve bronşlara giren partikül çapları Şekil 2'de verilmiştir (Kim ve diğ., 2015). Buna göre insan sağlığı açısından risk teşkil eden PM'ler 0,43 $\mu \mathrm{m}$ ile $11 \mu \mathrm{m}$ arasında değișmekte olup bronşlar ve alveollere kadar inen PM boyutları 2,1 - 0,43 $\mu \mathrm{m}$ arasındadır.

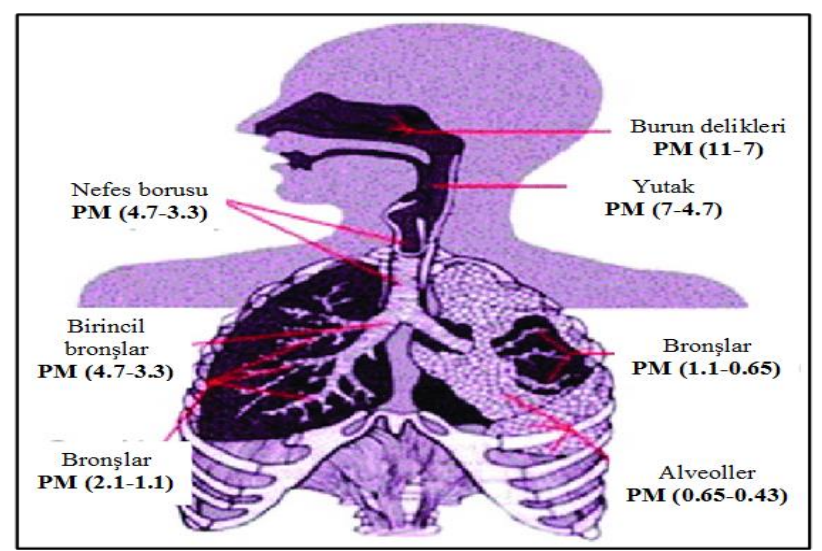

Şekil 2. Farklı Çapta Toz Partiküllerinin Vücudumuzdaki Toplanma Bölgeleri (Kim ve diğ., 2015)
Şekil 3'de görüldüğü üzere kömür madenciliği ve inşaat faaliyetlerindeki PM boyut aralıkları $1 \mu \mathrm{m}-100 \mu \mathrm{m}$ arasında değişmektedir. Ayrıca, Solunabilir (toplam toz); \%50'lik bölümü $100 \mu \mathrm{m}$ altında olan havadaki partikülleri, Torasik; \%50'lik bölümü $10 \mu \mathrm{m}$ altında olan havadaki partikülleri ve *Solunabilir; \%50'lik bölümü 4 $\mu \mathrm{m}$ altında olan havadaki partikülleri ifade etmektedir. Diğer taraftan solunabilir tozlar üst solunum yoluna, torasik akciğer hava yollarına ve *solunabilir akciğerlere kadar indiği için tehlikelidir. Kaynak dumanı toz partikül boyut aralığı en geniş olan partikül tipidir. Rüzgârın etkisiyle hareket eden toz partikül boyut aralığı da 1 - $100 \mu \mathrm{m}$ arasındadır.

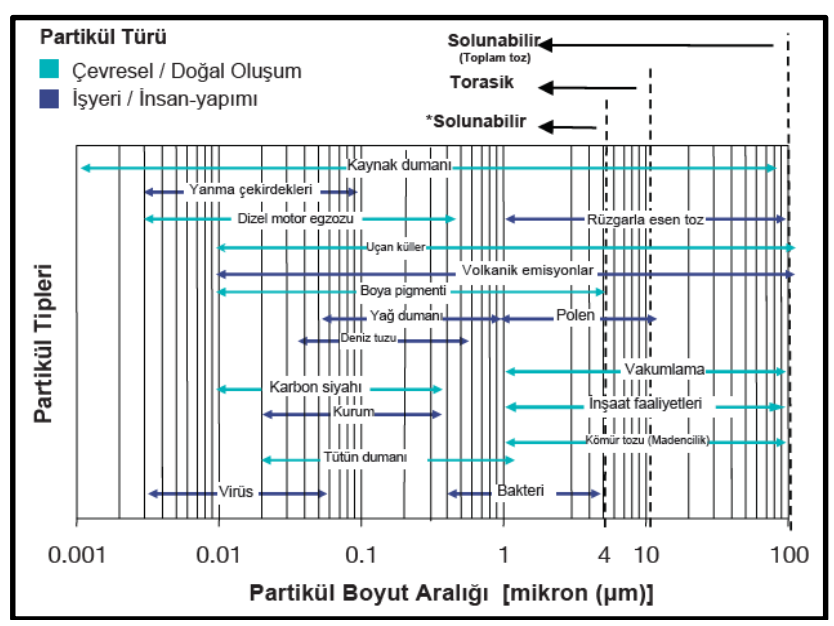

Şekil 3. Toz Partiküllerin Boyut Aralıkları (Dust, 2020)

Çeşitli partiküllerin boyutları Şekil 4'teki örneklendirme üzerinden gösterilmektedir. Buna göre insan sağlığı için tehlikeli olan $\mathrm{PM}_{10}$ çapı insan saçı çapından 5-7, ince sahil kumu çapından yaklaşık 9 kat daha düşüktür. $\mathrm{PM}_{2,5}$ çapı insan saçı çapından 20-28, ince sahil kumu çapından yaklaşık 36 kat daha küçüktür.

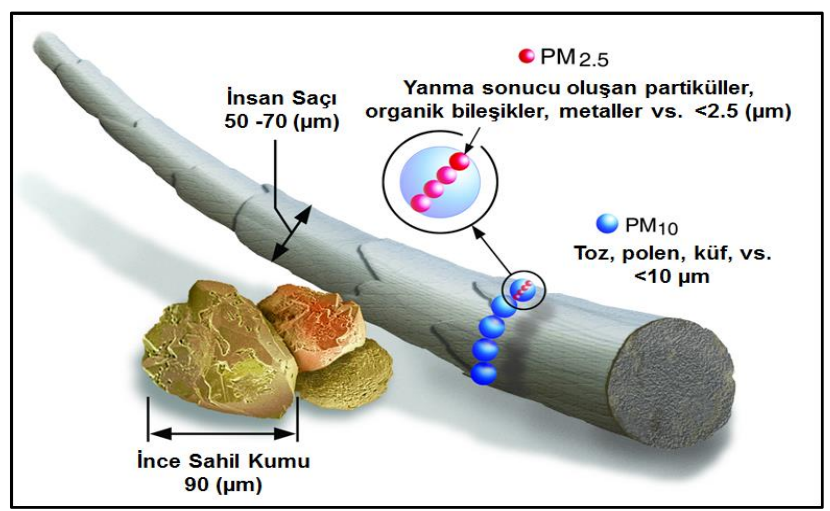

Şekil 4. Partikül Boyutlarının Örneklendirilmesi (Health Effects, 2020) 


\section{PM'lerin Olumsuz Etkileri}

Çok sayıda bilimsel çalışma, partikül madde kirliliğine maruz kalmanın değişik problemlerle ilişkili olduğunu göstermiștir. Bunlar arasında en belirgin olanları kalp veya akciğer rahatsızlığı olanlarda erken ölüm, ölümcül olmayan düzeyde kalp krizi, kalp atımlarının düzensiz çalışması, akciğer fonksiyonlarında düşüş, ağır astım, solunum yollarında tahriş, öksürük veya nefes alma güçlügü gibi artış gösteren solunum belirtileri ile kalp veya akciğer rahatsızlıkları sayılabilir. Çocuklar ve yaşlı insanlar partikül madde kirliliği maruziyetinden etkilenme olasılığı en yüksek olan gruplar olarak sayllabilmektedir (Kim ve diğ., 2015; THHP, 2019; Health Effects, 2020). Açık granit işletmeciliğinde çalışanlarda PM maruziyeti sonucu akciğer ve karaciğer ile ilgili olarak silikoz, bronşit, tüberküloz gibi hastalıklara yakalanma riski bulunduğu ve maden işletmesi çevresinde yaşayanların astım, göz problemleri, pnömokonyoz hastalı̆̆l, işitme problemleri ve cilt hastalıkları gibi meslek hastalıklarından etkilendiği ifade edilmiştir (Singh, Pal ve Khoiyanbam, 2009). Açlk maden işletmeciliğinde çalışan ve maden çevresinde yaşayanlarda PM maruziyetinden dolayı akciğer hastalıklarına, kardiyovasküler hastalıklara, böbrek hastalığına, depresyon, kanser dışı solunum hastalıklarına, kötü doğum sonuçları gibi değişik hastalıklara yakalanma riski bulunduğu (Laney ve Weissman 2014; Hendryx, 2015; Gautam, Patra, Sahu ve Hitch, 2016), ölüm oranlarının daha yüksek olduğu ifade edilmektedir (Arregoce's, Rojano, Angulo ve Restrepo, 2018).

Kurşun, arsenik, tungsten, gümüş, nikel, uranyum ve diğer radyoaktif minerallerin tozları solunum sisteminde kimyasal reaksiyonlara neden olabilmektedirler. Ayrıca, toksik bileşikler alveoller yardımıyla kan dolaşımının emilmesine izin verebilirler. Uranyum, asbest, arsenik veya kuvars tozu kansere neden olmakta olup diğer birçok toz akciğer dokusuna zarar vermektedir. Silika, asbest, mika, talk gibi fibrojenik tozlar en tehlikeli olanlarından bazıları olup toksik ve kanserojen reaksiyonlar üretebilirler (SIMRAC, 2003; Petavratzi, Kingman ve Lowndes, 2005).

Toz partiküllerinin çevresel anlamda olumsuz etkilerine bakıldığında, uzun mesafeler boyunca rüzgârla taşınmakta, zemine veya suya karışabilmektedir. Bu toz partiküllerinin olumsuz etkileri kimyasal içeriklerine göre değişkenlik göstermekle birlikte esas olarak; göl ortamlarının ve akarsu yataklarının asidik hale gelmesini, kıyı sularının ve büyük ırmak havzalarındaki besin dengesinin değişmesini, hassas nitelikteki orman ve bitki örtüsünün zarar görmesini ve ekosistemin çeşitliliğini etkileyip asit yağmuru oluşmasına neden olabilmektedir (Rahul ve Jain, 2014; Health Effects, 2020).

\section{4. İlgili Mevzuat}

Ülkemizde endüstriyel faaliyetlerden kaynaklanan toz salınımının (emisyon) değerlendirilmesi, 3 Temmuz 2009 tarihinde 27277 sayll Resmi Gazete'de yayımlanan ve 20 Aralı 2014 tarihinde 29211 saylı Resmi Gazete'de değiştirilen Sanayi Kaynaklı Hava Kirliliğinin Kontrolü Yönetmeliği (SKHKKY) esas alınarak gerçekleştirilmektedir (Tablo 1). Bu yönetmeliğe göre maden işletmelerindeki faaliyetlerde (patlatma, sökme, yükleme, boşaltma, nakliye vb.) açı̆̆a çıkan toz salınımının kütlesel debi hesaplamalarında kullanılacak emisyon faktörlerinin kestirimi için Yönetmelik Ek - 1'deki 'Taş Çıkarma, Kırma ve Sınıflandırma Tesisleri" bașlı̆̆ı altındaki emisyon faktörlerinin değerlendirilmesi, kontrollü ve kontrolsüz durumlar için yapılmaktadır.

$\mathrm{Bu}$ yönetmeliğe göre; havada asılı $\mathrm{PM}_{10}$ sınır değeri 2019 ve sonraki yıllar için günlük $50 \mu \mathrm{g} / \mathrm{m}^{3}$ ve yıllık 40 $\mu \mathrm{g} / \mathrm{m}^{3}$ olarak belirlenmiş olup madencilik sektöründe salınım faktörlerinin hesaplanma detayları ile ilgili referans denklemler verilmemiştir.

Ülkemizde Tozla Mücadele Yönetmeliği, 05 Kasım 2013 tarihinde 28812 sayılı Resmî Gazete'de yayımlanmıştır. Bu Yönetmelik, 20/6/2012 tarihinde yürürlüğe giren 6331 sayılı İş Sağlığı ve Güvenliği Kanunu kapsamına dahil olan ve çalışanların yaptıkları faaliyetler sırasında toza maruz kalabilecekleri ișyerlerinde uygulanmaktadır. Yönetmeliğe göre solunabilir tozun tanımı yapılmış olup sınır değeri $5 \mathrm{mg} / \mathrm{m}^{3}$ tür. Ayrıca bu yönetmelikte, toz ölçüm metodunun nasıl yapılacağı ve zaman ağırlıklı ortalama değerin (ZA-OD/TWA) ne anlama geldiği de ifade edilmektedir.

Diğer yandan ülkemizde ve gelișmiş ülkelerde halihazırda yürürlükte olan ilgili yönetmelikler ve standartlarda belirtilen partikül madde $\left(\mathrm{PM}_{10}\right.$ ve $\left.\mathrm{PM}_{2,5}\right)$ ile ilgili sınır değerler Tablo 2'de sunulmuştur. Buna göre, ülkemizde ilgili yönetmelikte sadece $\mathrm{PM}_{10}$ ile ilgili sınır değer olmasına karşın, ABD, Kanada, Avustralya ve $\mathrm{AB}$ üyesi ülkeler ile Dünya Sağlık Örgütü (WHO) $\mathrm{PM}_{10}$ yanında $\mathrm{PM}_{2,5}$ ile ilgili sınır değerler de tanımlamıştır.

Ülkemizde PM10 örneklemesi ve ölçümü 6 Haziran 2008 tarihinde 26898 sayılı Resmi Gazete'de yayımlanan Hava Kalitesi Değerlendirme ve Yönetimi Yönetmeliği (HKDYY) esas alınarak yapılmaktadır. Yönetmelikte $\mathrm{PM}_{10}$ örneklemesi ve ölçümü için hangi referans metodun kullanılacağı belirtilmektedir. Yönetmeliğe göre $\mathrm{PM}_{10}$, filtre üzerinde toplanmakta ve gravimetrik kütle tayini yöntemi esas alınmaktadır. Ayrıca yine ilgili yönetmelikte belirtilen referans metotla aynı sonuçları veren başka bir metodun da kullanılabileceği ifade edilmektedir. Diğer taraftan aynı yönetmelikte, $\mathrm{PM}_{2,5}$ örneklemesi ve ölçümü için Bakanlık (Çevre ve Orman Bakanlığı) tarafından uygun olduğu düşünülen başka bir ölçüm metodunun Bakanlığa bildirilmesi koșuluyla da kullanılabileceği belirtilmektedir (ÇOB, 2008). 
Ortam havasındaki $\mathrm{PM}_{10}$ kütle konsantrasyonunun belirlenmesi EN 12341 veya EPA 40 CFR PART 50, PM 2,5 kütle konsantrasyonu EN 14907 standartlarına uygun olarak yapılmaktadır. Avrupa Birliği, birinci hava kalitesi direktifine (1999/30/EC) göre $\mathrm{PM}_{10}$ ölçümlerinin EN 12341 Avrupa Standardında tanımlandığı gibi referans yöntem kullanılarak yapılması gerektiğini belirtmiștir. $\mathrm{Bu}$ standart, kullanılabilecek "çok yüksek hacimli örnekleyiciWRAC", yüksek hacimli örnekleyici-HVS $\left(\mathrm{PM}_{10}\right.$ örnekleyici-1.133,33 L/dak) ve düşük hacimli örnekleyici-LVS (PM 10 örnekleyici-38,33 L/dak) üç örnekleme cihazını önermektedir. Çok yüksek hacimli örnekleyiciler genellikle 'birincil standart' olarak kabul edilmekle birlikte genel çalıșma ortamlarına yerleştirilmeleri uygun değildir (Pilling ve diğ., 2005). Düşük hacimli örnekleyiciler sıklıkla kullanılmaktadır (Chakraborty ve diğ., 2002; Pilling ve diğ., 2005; Catrambone ve diğ., 2019; Tripathy ve Dash, 2019; Richardson, Rutherford ve Agranovski, 2019).

Tablo 1

Tesis Etki Alanında Uzun Vadeli (UVS) ve Kısa Vadeli (KVS) Sınır Değerler ve Azaltım Tablosu (ÇŞB, 2014)

\begin{tabular}{|c|c|c|c|c|c|c|}
\hline \multirow[t]{2}{*}{ Parametre } & \multirow[t]{2}{*}{ Süre } & \multirow{2}{*}{$\begin{array}{r}\text { Sinır değer }\left[\mu \mathrm{g} / \mathrm{m}^{3}\right] \\
\text { Çöken toz }\left[\mathrm{mg} / \mathrm{m}^{2} \text {-gün] }\right.\end{array}$} & \multicolumn{4}{|c|}{ YIL } \\
\hline & & & 2017 & 2018 & $2019-2023$ & 2024 ve sonrası \\
\hline \multirow{2}{*}{$\begin{array}{l}\text { Havada asılı partikül } \\
\text { madde }\left(\mathrm{PM}_{10}\right)\end{array}$} & $\begin{array}{l}24 \text { saatlik (yılda en fazla } \\
35 \text { kez assılabilir) }\end{array}$ & $100^{*}$ & 70 & 60 & 50 & 50 \\
\hline & Yillık & $60 *$ & 48 & 44 & 40 & 40 \\
\hline \multirow{2}{*}{ Çöken toz } & KVS & $390 *$ & 390 & 390 & 390 & 390 \\
\hline & UVS & $210^{*}$ & 210 & 210 & 210 & 210 \\
\hline
\end{tabular}

*Sınır değer 2024 yılı hedeflerine ulaşılasıya kadar yıllık eşit olarak azaltılacaktır.

Tablo 2

Ülkemizde ve Gelişmiş Ülkelerde Partikül Madde (PM10 ve PM2,5) Sınır Değerleri (Ren, Yang ve Bai, 2017; NAAQS 2020; CCME, 2020; NSW, 2020; EC, 2020)

\begin{tabular}{|c|c|c|c|c|c|c|c|c|}
\hline \multirow{2}{*}{ Parametre } & \multirow{2}{*}{ Ortalama süre } & \multicolumn{7}{|c|}{ Sinır değer $\left(\mu \mathrm{g} / \mathrm{m}^{3}\right)$} \\
\hline & & Türkiye & $\mathrm{ABD}$ & Kanada & Avustralya & Çin & WHO & $\mathrm{AB}$ \\
\hline \multirow{2}{*}{$\mathrm{PM}_{2,5}$} & 24 saatlik & - & 35,0 & iii15,0 - iv27,0 - v28,0 & 25,0 & v135,0- vil75,0 & 25,0 & - \\
\hline & Yillık & - & $\mathrm{i} 12,0-\mathrm{ii} 15,0$ & 8,8 & 8,0 & v1 $15,0-$ vi135,0 & 10,0 & 25,0 \\
\hline \multirow{2}{*}{$\mathrm{PM}_{10}$} & 24 saatlik & 50,0 & 150,0 & 25,0 & 50,0 & v150,0-vı150,0 & 50,0 & 50,0 \\
\hline & Yıllık & 40,0 & - & - & 25,0 & vi 40,0 - vı170,0 & 20,0 & 40,0 \\
\hline $\begin{array}{l}\text { i Birincil stand } \\
\text { ii İkincil standa } \\
\text { iii CEPA standa }\end{array}$ & $\begin{array}{l}\text { (halk sağlığ }) \\
\text { (diğer canlılar, bi }\end{array}$ & tüsü ve $\mathrm{k}$ & $\begin{array}{l}{ }^{\mathrm{v}} \mathrm{C} \\
{ }^{\mathrm{v}} \mathrm{N} \\
{ }_{\mathrm{vil}} \mathrm{I}\end{array}$ & $\begin{array}{l}\text { S standardı } \\
\text { li parklar gibi özel bölge } \\
\text { ntsel ve endüstriyel alar }\end{array}$ & lâhil tüm ala & iv NAAQO & andard & \\
\hline
\end{tabular}

\section{PM Salınım Miktarının Belirlenmesi}

Açlk işletme madencilik faaliyetlerinin proje aşamalarında ve çalışma faaliyetleri sırasında açığa çıkan toz emisyonlarının gerçeğe yakın olarak hesaplanması hava kalitesi yönetimi için son derece önemlidir. USEPA (1995), salınımın tahmin yaklaşımlarının değişik ölçüm metotlarıyla belirlenmesi durumunda, kullanılacak metotların tahmin güvenirliliği ve maliyeti arasındaki ilişki yönünden Şekil 5'de sunulan risk analizi diyagramı ile ortaya koymuş ve toz salınımı tahmininde kaynağa özgü "sürekli salınım ölçümleri ve/veya salınım testleriyle" elde edilen sonuçların, salınım miktarının belirlenmesinde en iyi yöntem olduğunu ifade etmiştir. Ancak herhangi bir kaynağa ait sürekli salınım ölçümleri ve/veya salınım testi yoksa belirli bir zaman aralığında (yıllık veya günlük gibi) mevcut çalışma şartlarını en iyi şekilde temsil edecek bir ölçüm alınması gerektiğini belirtmiștir. Kütle denkliği metodunda, malzemenin birinci basamağında belirlenmiş olan girdi miktarının son evreye gelene kadar ki salınımlar dahil tüm ürünlerin hesaba katılması gerekmektedir. Bu metot, atmosfere yüksek oranlarda salınım olması durumunda kullanımı uygundur. Ölçüm süresi boyunca salınımdaki kısa süreli ani dalgalanmalar tahmini etkilemediğinden dolayı, uzun vadeli salınım miktarının doğru tahmin edilmesi mümkün olabilmektedir. Toz salınım miktarının hesabında yukarıda bahsedilen ölçüm tekniklerinin (örnekleme/ölçme ve kütle denkliği) uygulanmasının mümkün olmadığı durumlarda, son çare olarak AP-42 emisyon faktörleri kullanılabilir. Ancak bu emisyon faktörlerinin kullanılması durumunda, herhangi bir tesisteki salınım miktarının doğru tahmin edilmesinin sınırlı ve riskli olabileceği unutulmamalıdır. $\mathrm{Bu}$ ölçüm metotları dışında, malzemenin kendine özgü fiziksel ve/veya kimyasal özellikleri ile matematiksel denklemleri kullanarak mühendislik değerlendirmelerin yapılması ve farklı ülkelerin yönetimleri tarafından kabul görmüş standartlar/yönetmelikler diğer ölçüm teknikleri olarak sayılabilmektedir (USEPA, 1995; Beşir, 2015). 
Diğer taraftan, Avustralya Hükümeti Sürdürülebilirlik, Çevre, Su, Nüfus ve Toplulukları Bölümü Madencilik sektöründeki emisyonların tahmin edilebilmesi için Ulusal Kirletici Envanterini (NPI) oluşturmuştur. Bu envanterde emisyonların tahmin edilebilmesinde kullanılmak üzere; yerinde doğrudan ölçüm veya numune alma, kütle dengesi, yakıt analizi veya diğer mühendislik değerlendirmeleri, salınım faktörleri ve onaylanmış alternatifler olarak beş adet ölçüm tekniği önermektedir. Ayrıca NPI, yapılan işin niteliğine göre uygun yöntemin seçilmesi gerektiğini de belirtmiştir (NPI, 2012; Beşir, 2015).

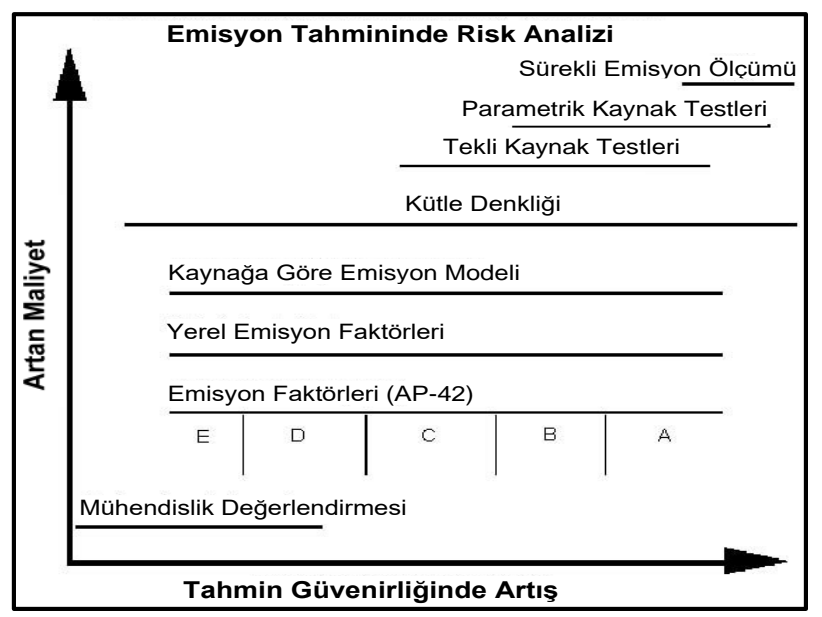

Şekil 5. Salınım Tahmin Yaklaşımı (USEPA, 1995)

\section{Açık İșletme Faaliyetleri Kaynaklı PM Salınımı}

Literatürde, açık işletmecilik faaliyetleri sonucu açı̆̆a çıkan PM salınımlarının belirlenmesi amacıyla sahaya özgü değişik yaklaşımlar bulunmaktadır. USEPA (1998) tarafindan sunulan AP-42 "Revised Final Report" salınım faktörlerinin kullanılmasını önermektedir. Ancak AP-42' de sunulan salınım faktörleri ve hesaplama metotları kömür madenlerine yönelik oluşturulmuş olup başka bir seçenek olmadığından dolayı kömür dıșı maden ocaklarında da kullanılabilmektedir. AP42'de açık kömür madenciliği ile ilgili sahaya özgü salınım faktörleri ile ilgili bilgiler verilmektedir. Madencilik faaliyetleri sonucu açığa çıkan PM miktarı; sahaya özgü meteorolojik faktörlere (rüzgâr hızı ve yönü, hava nemi, sıcaklık vb.), ekipman özelliklerine (kepçe/kova kapasitesi, kamyon seyir hızı, çalışma periyodu vb.) ve malzemenin kendine özgü fiziksel özelliklerine (nem ve silt içeriği) bağlı olarak değişmektedir (USEPA, 1998; Patra ve diğ., 2016).

Açık kömür işletmeciliği sırasında önemli oranlarda toz salındığı, açığa çıkan toz ile ilgili salınım faktörlerinin sahaya özgü olduğu ve bir saha için geliştirilen faktörlerin başka bir sahada doğru sonuçlar veremeyeceği, bunun için salınım faktörlerinin her bir saha için uyarlanması gerektiği belirtilmiştir (Ghose,
2004; Huertas, Camacho ve Huertas, 2012). Açık kömür işletmeciliğinde toz salınımı faaliyet türüne (delme, yükleme, taşıma vb.) göre değişiklik gösterdiği, salınım denklemlerinin malzemenin kendine özgü fiziksel özelliklerine (nem ve silt içeriği), ekipman özelliklerine (kepçe/kova kapasitesi, kamyon seyir hızı, çalışma periyodu vb.) ve rüzgâr hızına bağlı olarak değiştiği ve daha tutarlı kestirim denklemlerinin geliştirilmesi için daha fazla çalışma yapılması gerektiği ifade edilmiştir (Ghose, 2004; Lashgari ve Kecojevic, 2016).

Madencilik faaliyetlerinden kaynaklanan tozun maden sahasındaki çevre, insan sağlığl, iş emniyeti ve verimliliğine etki eden önemli bir konu olduğu ifade edilmiştir (Petavratzi ve diğ., 2005; Ghose ve Majee 2007; Papagiannis, Roussos, Menegaki ve Damigos, 2014; Tripathy, Dash, Badu ve Kanungo, 2015). Ayrıca çalışanların toz maruziyetinden korunması için mümkün olduğunca çok sayıda ölçüm yapmanın yanında kılavuz ve standartların oluşturulması ve benimsenmesi gerektiği de önerilmektedir (Petavratzi ve diğ., 2005; Ghose ve Majee, 2007).

Açık işletme kaynaklı partikül maddelerin birincil kirletici, $30 \mu \mathrm{m}$ ve üzeri toz partiküllerinin TAPM olduğu, $30 \mu \mathrm{m}$ ile $10 \mu \mathrm{m}$ arasındaki toz partiküllerin belirli bir süre için havada askıda kaldığı ve sağlık açısından risk teşkil ettiği ifade edilmiştir. Ayrıca 10 $\mu$ m'den daha küçük toz partiküllerin solunabilir olduğu ve 2,5 $\mu \mathrm{m}-1 \mu \mathrm{m}$ arasındakilerin ise akciğerlere kadar indiği belirtilmiştir. $\mathrm{Bu}$ yüzden madencilik faaliyetlerinden kaynaklanan toz salınımı tahmini için daha çok $10 \mu \mathrm{m}$ ve daha düşük çaplı toz tanecikler üzerinde yoğunlaşılması gerektiği belirtilmiștir (Patra ve diğ., 2016).

Açık kömür işletmelerinin yeraltı kömür madenlerine göre toz salınımı bakımından çevreyi daha fazla kirlettiği ve ana kirletici kaynaklardan birinin toz olduğu ifade edilmiştir. Hindistan'da bulunan bir açık kömür işletmesinde bir yll boyunca beș noktada hava kalitesi ölçümü yapılmıştır. Buna göre TAPM 3723 $\mu \mathrm{g} / \mathrm{m}^{3}$, solunabilir toz partikülün $\left(\mathrm{PM}_{10}\right) 720 \mu \mathrm{g} / \mathrm{m}^{3}{ }^{\prime} \mathrm{e}$ kadar çıktığı ve insan sağlığl için risk oluşturduğu belirtilmiştir (Ghose ve Majee, 2007). Başka bir çalışmada yine Hindistan'da bulunan iki açık kömür madenine meteorolojik verilerin ölçülmesi için istasyon kurularak, delicilerin çalışması sırasında açığa çıkan tozun salınımları hesaplanmıştır. Birinci kömür madeninde toz salınım değerlerinin $90 \mu \mathrm{g} / \mathrm{m}^{3}$ ila 380 $\mu \mathrm{g} / \mathrm{m}^{3}$, ikinci kömür madeninde $275 \mu \mathrm{g} / \mathrm{m}^{3}$ ila 662 $\mu \mathrm{g} / \mathrm{m}^{3}$ arasında olduğu hesaplanmıştır (Nagesha, Sastry ve Ram, 2016). Diğer bir çalışmada ise Tripathy ve diğ. (2015), açık kömür madeninde delme işlemi sırasında $\mathrm{PM}_{10}$ için maksimum ve ortalama toz konsantrasyonunun $150,0 \mathrm{mg} / \mathrm{m}^{3}$ ve $26,8 \mathrm{mg} / \mathrm{m}^{3}$, yükleme noktasında minimum ortalama toz konsantrasyonunun $\quad 0,474 \quad \mathrm{mg} / \mathrm{m}^{3} \quad$ olduğunu bildirmiștir. 
Nagesha ve diğ. (2016) Hindistan'da bulunan açık kömür işletmesinde oluşan toz için çoklu regresyon yöntemiyle tahmin modelleri geliștirip, USEPA ile karşılaştırmış ve her iki model arasında farklılık olduğunu ifade etmiştir. Benzer bir çalışmada Richardson ve diğ. (2019) Avustralya'nın iki farklı bölgesinde bulunan açlk kömür işletmelerinde $\mathrm{PM}_{2,5}$ salınımı ölçümü yapmıștır. Ocaklar arasında salınım bakımından önemli farkların olduğunu ve bunun temel nedeninin malzemenin silt ve nem içeriğinden kaynaklandığını bildirmişlerdir. Ölçüm sonuçlarının AP42 ve NPI tahmin modelleriyle mukayesesi yapılmış ve farklılıklar olduğu belirtilmiştir. Martin ve diğ. (2007) de İspanya'da bir limanda bulunan klinker, silika-mangan, un, soya fasulyesi ve toz kömürün yükleme, boşaltma ve taşıma aşamalarında meydana gelen partikül madde emisyonlarını ve atmosferik koșulları düzenli aralıklarla kaydederek, bu verileri bir modelde kullanmıșlardır. Modelde ayrıca AP-42'de yükleme, taşıma ve boşaltma aşamaları için verilen faktörlerle de salınımlar hesaplanıp, sonuçları da karşılaştırılmıștır. Genel olarak USEPA'nın geliştirdiği AP-42 salınım faktörlerinin ölçüm değerleriyle uyumlu olduğu belirtilmiştir. Dünyanın en büyük kömür madenciliği faaliyetlerinden birine ( $\sim 70 \mathrm{Mt} / \mathrm{yll})$ ev sahipliği yapan Kolombiya'nın kuzey kesiminde faaliyet gösteren sekiz maden işletmesinden yedisinde toz salınımı tahmini için çalışma yapılmıştır. Öncelikle verinin doğruluk analizi yapılarak salınım envanteri metodu uygulandığında geçerli bir sonuç verip veremeyeceği değerlendirilmiştir. Bunun için USEPA AP-42 salınım faktörleri ile hesaplanan TAPM ve $\mathrm{PM}_{10}$ arasında doğrusal ilgileşim analizi incelenmiş ve üretim ile PM salınımı arasında yüksek bir doğrusal ilgileşim olduğu sonucuna varılmıștır (Huertas ve diğ., 2012).

Hesaplamalı akışkanlar dinamiği (CFD) modeli ile dengedeki hava koşullarında bir taş ocağındaki partikül madde salınımlarının açık ocağın içinde dağılımı modellenmiştir. Buna göre, beş ayrı patlatma işlemi sonucu oluşan toplam tozun dağılımının incelenmesiyle, bu tozların rüzgârın yönüne bağlı olarak dengedeki koşullar altında \%30 ile \%60'lık kısımlarının açık ocak sınırları içerisinde dağıldıkları sonucuna varılmıştır. Toz salınımlarının derin açık ișletmelerden veya agrega ocaklarından yayılmasının modellenmesinde en büyük zorluğun açık ocak çukurundaki meteorolojik koşulların etkisinin olduğunu ve Gauss modelinin bu tür ocaklarda meteorolojik davranışları ihmal ettiğini, dolayısıyla bu modelin düz ve düze yakın arazilerde daha iyi sonuç verebileceğini ifade etmişlerdir (Silvester, Lowndes ve Hargreaves, 2009). Diğer taraftan İngiltere'de bulunan iki taş ocağında patlatma, yükleme, taşıma ve stok alanlarında oluşan tozun yayılımı USEPA AP-42 dokümanındaki salınım faktörleri kullanılarak atmosferik dispersiyon modelleme yazılımı ile modellenmiştir. 2002 yılındaki hava bilgisi tahminleri ile ilgili veriler ve farklı hava bilgisi koşullarının incelenmesi amaciyla Pasquill-Gifford duraylılık katsayıları kullanılmıștır. Buna göre, patlatma sırasında açığa çıkan tozun (PM $\left.{ }_{75}\right) 1900 \mathrm{~kg} /$ patlatma olduğu, bir saat boyunca salınıyormuş gibi simüle edilmesi sonucu $33 \mathrm{~g} / \mathrm{s}$ salınım olduğu hesaplanmıștır. Modelde noktasal salınım kaynakları sınırlı olduğu için hem açık ocak sahası hem de nakliye yolu için dizilmiş noktasal salınım kaynakları tanımlanmıştır. Arazi yapısının incelenmesi sonucu yapılmış olan modellemede patlatma sonrası ve nakliye yolunda oluşan toz salınımları için iki farklı toz dağılımı elde edilmiştir. Sonuç olarak bölgeye özgü meteorolojik koşulların ve arazi yapısının toz dağılımı üzerindeki etkisinin önemli olduğunu ifade edilmiștir (Appleton, Kingman, Lowndes ve Silvester, 2006). Açık ocak madenlerinde toz kirliliğinin önemli bir sorun olduğu, delme, patlatma, nakliye ve diğer madencilik faaliyetlerinin temel toz kaynağı olduğu ifade edilmiştir. Hindistan'da bulunan Lakhanpur açı kömür işletmelerindeki farklı çalışma alanlarındaki toz seviyelerinin izlenmesi, farklı kaynaklardan toplanan tozun karakterize edilmesi, kişisel toz maruziyetlerinin hesaplanması ve bir paket programından faydalanılarak madenlerin farklı bölgelerinde ve yakın alanlardaki toz konsantrasyonlarının tahmin edilmesine yönelik bir çalışma yapılmıştır. Çalışma sonucunda, işletmeler arasındaki toz salınımlarının farklı olduğu ve çalıșanların çoğunun izin verilebilir sınır değerlerinden daha fazla toza maruz kaldıkları ifade edilmiştir. Ayrıca maden işletmelerindeki ana toz kaynağı ekipmanlarının delici makine ve döner kepçeli ekskavatörlerin olduğu da belirtilmiştir (Tripathy ve diğ., 2015).

Yunanistan'da bulunan bir linyit ișletmesinde toz salınımını hesaplamak için 52 farklı çalışma bölgesindeki veriler kullanılarak Ghose (2004) ve NPI (2012) tarafından önerilen denklem ve salınım faktörleri kullanılmıştır. Sonuç olarak iki farklı çalışma tarafından önerilen denklem ve salınım faktörleri kullanılarak hesaplanan emisyon değerleri arasında farklılıklar olduğu ifade edilmiştir (Papagiannis ve diğ., 2014). Diğer taraftan ABD'de bulunan bir açık kömür ișletmesindeki elektrikli ekskavatör ve lastik tekerlekli yükleyicilerin toz salınımının karşılaştırmalı analizi yapılmıştır. Bunun için saha ölçümleri ve laboratuvar çalışmaları ile toz salınımı üç farklı yöntemle tahmin edilmiștir. Birinci yöntemde EPA AP-42 salınım faktörü kestirim denklemleri, ikinci yöntemde AP-42 denklemlerinin geliştirilmesinde kullanılan metodoloji (Tip 2 toz salınım tahmini) ve üçüncü yöntemde EPA AERMOD modelinde kullanılan metodolojiden (Tip 3 toz emisyon tahmini) faydalanılmıștır. Sonuçta, AP-42 toz salınım tahmin yöntemiyle elde edilen toz salınımının, Tip 2 ve Tip 3 toz salınım tahmin yöntemleriyle belirlenen alan bazlı salınımı aştığı ortaya çıkmıştır. Ayrıca Tip 2 yöntemiyle belirlenen toz salınımı Tip 3'den fazla çıkmıştır (Lashgari ve Kecojevic, 2016).

Ülkemizde bulunan bir açık kömür işletmesinde en yüksek kişisel toz konsantrasyonuna 3,08 mg/m $\mathrm{m}^{3}$ ile delici operatörünün, en düşük kişisel toz 
konsantrasyonuna ise $1,3 \mathrm{mg} / \mathrm{m}^{3}$ ile kömür yükleyici operatörünün maruz kaldığı hesaplanmıştır (Önder ve Yiğit, 2009). Yapılan bir araştırmada üç farklı açık ocak işletmesinde çalışan iş makinası operatörlerinin kişisel toz maruziyetinin ölçüm sonuçlarına bakıldığında, delici ve paletli iş makinesi operatörlerinin maruz kaldıkları toz konsantrasyonu değerlerinin yüksek olduğu belirtilmiștir. Diğer taraftan, tüm operatörlerin maruz kaldığı toz konsantrasyonu değerlerinin ise ilgili yönetmelikte belirtilen maruziyet sınırının altında olduğu ifade edilmiştir (Öztürk, 2016). Diğer bir araştırmada ise, üç çimento fabrikasında yapılan 24 adet solunabilir toz ölçümü ile A çimento fabrikasında çalışan personelin kişisel toz maruziyet değerleri $0,02 \mathrm{mg} / \mathrm{m}^{3}$ $22,32 \mathrm{mg} / \mathrm{m}^{3}$, B çimento fabrikasında $0,06 \mathrm{mg} / \mathrm{m}^{3}-5,08$ $\mathrm{mg} / \mathrm{m}^{3}$ ve C çimento fabrikasında $2,9 \mathrm{mg} / \mathrm{m}^{3}-10,64$ $\mathrm{mg} / \mathrm{m}^{3}$ arasında değiștiği hesaplanmıștır (Balcı, 2016). Konya ili Selçuklu ilçesinde bulunan bir mermer işleme tesisinde çalışanların toz maruziyetleri için 76 adet toz ölçümü ve her birim için en az 60 adet toz ölçüm değeri alınıp, bu değerlerin ortalaması alınarak en yüksek toz maruziyetinin "Köprülü kesme ve yarma" makinelerinde, en düșük toz maruziyetinin "Eskitme kazanı" ünitesinde olduğu ve ölçüm sonuçlarının Tozla Mücadele Yönetmeliğinde belirtilen sınır değerlerinin altında olduğu ifade edilmiştir (Çınar ve Şensögüt, 2017). Agrega tesisinde toz maruziyetine yönelik yapılan çalışmada işçilerin kişisel toz maruziyeti 4,51 $\mathrm{mg} / \mathrm{m}^{3}$, delme-patlatma sahasında çalışan personelin $2,22 \mathrm{mg} / \mathrm{m}^{3}$ ve stok alanında çalışan personelin 3,92 $\mathrm{mg} / \mathrm{m}^{3}$ bulunmuştur (Miçooğulları, 2018).

Ülkemizdeki bir açık kömür işletmesinde 1994-2005 yılları arasında; dekapaj ve kömür yükleme sahalarında, stok sahasında, delicide ve kömür eleme tesisinde alınan kişisel toz ölçüm verileri varyans analizi ve TukeyKramer prosedürü kullanılarak değerlendirilmiștir (Önder ve Yiğit, 2009). Türkiye Taşkömürü Kurumu (TTK) yeraltı kömür ocaklarında solunabilir toz içindeki kül ve kuvars miktarı sistematik olarak ölçülmüş ve istatistiksel değerlendirmesi yapılmıștır. Ocaklar arasında ortalama toz yoğunluğu, kül ve kuvars oranlarının birbirinden farklı olduğu sonucuna varılmıştır (Erol, 2012).

Dünyada açık maden işletmelerinde sürdürülen faaliyetlerden kaynaklanan PM salınım oranlarını tahmin etmede kullanılan parametreler Tablo 3'te, PM salınım tahmin formülleri Ek 1'de verilmiştir. Buna göre, PM salınım formüllerinin çıkarılmasında kullanılan parametrelerin faaliyet türüne bağlı olarak değiştiği, nem ve silt içeriği, rüzgâr hızı ve makine özellikleri gibi değişkenlerin daha sıklıkla kullanıldığı gözlemlenmiştir. Diğer yandan bu formüller çoğunlukla kömür madenciliği, kısmen de demir madenciliği için geliştirilmiştir. PM salınım formülleri çoğunlukla TAPM olmak üzere; $\mathrm{PM}_{15}, \mathrm{PM}_{10}$ ve $\mathrm{PM}_{2,5}$ gibi parametreler için de türetilmiştir. Diğer bir bakış açısından ise PM salınım tahmin formüllerinin en çok delme, yükleme ve taşıma gibi temel madencilik faaliyetleri için geliştirilmiş olduğu tespit edilmiştir.

Tablo 3

Açık İşletme Faaliyetlerinde PM Salınım Tahmin Formüllerinde Kullanılan Parametreler

\begin{tabular}{|c|c|}
\hline Faaliyet & Ölçülen ve hesaplanan parametreler \\
\hline \multirow{5}{*}{ Delme } & Nem içeriği (\%) \\
\hline & Silt içeriği (\%) \\
\hline & Rüzgâr hızı (m/s) \\
\hline & Delik çapı (mm) \\
\hline & Delme sıklığı (delik/gün) \\
\hline \multirow{3}{*}{ Patlatma } & Nem içeriği (\%) \\
\hline & Patlatma alanı $\left(\mathrm{m}^{2}\right)$ \\
\hline & Patlatma deliği boyu (m) \\
\hline \multirow{6}{*}{ Yükleme } & Nem içeriği (\%) \\
\hline & Silt içeriği (\%) \\
\hline & Rüzgâr hızı (m/s) \\
\hline & Malzeme boșaltma yüksekliği (m) \\
\hline & Yükleyici kapasitesi $\left(\mathrm{m}^{3}\right)$ \\
\hline & Yükleme sıklığı (sayı/saat) \\
\hline \multirow{8}{*}{ Taşıma } & Taşıma yolunun nem içeriği (\%) \\
\hline & Taşıma yolunun silt içeriği (\%) \\
\hline & Rüzgâr hızı (m/s) \\
\hline & Ortalama araç hızı (km/saat) \\
\hline & Kamyonun toplam kütlesi (ton) \\
\hline & Kamyonun kapasitesi (ton) \\
\hline & Kamyon hareket sıklığı (sayı/saat) \\
\hline & Tekerlek sayısı \\
\hline \multirow{6}{*}{ Boşaltma } & Boşaltma malzemesinin nem içeriği (\%) \\
\hline & Boşaltma malzemesinin silt içeriği (\%) \\
\hline & Rüzgâr hızı (m/s) \\
\hline & Malzeme boşaltma yüksekliği (m) \\
\hline & Boşaltma sıklı̆̆ı (sayı/gün) \\
\hline & Kamyonun kapasitesi (ton) \\
\hline \multirow{2}{*}{$\begin{array}{l}\text { Küreme } \\
\text { (Dozer) }\end{array}$} & Nem içeriği $(\%)$ \\
\hline & Silt içeriği (\%) \\
\hline $\begin{array}{l}\text { Siyırma } \\
\text { (Greyder) }\end{array}$ & Ortalama araç hızı (km/saat) \\
\hline
\end{tabular}

\section{Sonuçlar}

Açık maden işletmelerinde PM salınımı üzerine yapılan literatür araştırması niteliğindeki bu çalışmada aşağıdaki sonuçlara varılmıştır.

Madencilik sektöründe hava kirliliğine neden olan faktörlerin düşük düzeye indirilebilmesi mümkündür. Bunun için salınım kaynağına bağlı sürekli ölçüm yapılmalı, kaynağa göre PM salınımları/faktörleri belirlenmeli ve faaliyet türüne bağlı olarak toz azaltma teknikleri uygulamaya konulmalıdır. Böylece, işletme çevresindeki bölgelerin de etkilenmesinin önüne geçilebilir. 
Açık işletmelerde sürdürülen faaliyetlerden kaynaklı PM salınımlarının tahmini üzerine yapılan uluslararası çalıșmalar derlendiğinde, PM salınım denklemlerinin çoğunlukla kömür madenlerine dönük olarak geliştirildiği ve diğer açık işletme faaliyetlerinin AP-42 ile NPI emisyon faktörlerini referans aldığı görülmektedir. Açık işletme madenciliğinde PM salınımı tahmin denklemlerinde çoğunlukla nem ve silt içeriği gibi malzeme özellikleri ile atmosferik parametreler arasından rüzgâr hızından faydalanılırken, en sıklıkla TAPM ve PM 10 faktörleri modellenmektedir.

Ülkemiz mevzuatında madencilik faaliyetleri kaynaklı PM salınımına ait kütlesel debi hesaplamaları için SKHKKY Yönetmeliği Ek - 1'deki "Taş çıkarma, Kırma ve Sınıflandırma Tesisleri" başlı̆̆ı altında kontrollü ve kontrolsüz durumlar için emisyon faktörleri sayısal değer olarak verilmiştir. Bu faktörler tüm operasyonlar, faaliyetler ve cevher tipleri için geçerlidir. Ancak, çeşitli araştırmacılar tarafından maden işletmeleri için geliştirilen PM salınım tahmin denklemlerinin aynı operasyon için bile işletmeler arasında değişkenlik gösterdiği, bu nedenle tahmin modellerinin madene özgü olmasının doğru bir yaklaşım olacağı sonucuna varılmıștır. Bunun sonucu olarak maden ișletmeleri faaliyete başlamadan önce, PM tahmin salınımı için faaliyet türüne bağlı olarak Ek 1'de verilen görgül formüllerden de yararlanılabilir.

Ülkemizdeki madenlerde toz salınımının belirlenmesi için yapılan çalışmalar değerlendirildiğinde, bunların büyük oranda kömür madenlerinde ve kișisel toz maruziyeti amacıyla yapıldığı tespit edilmiştir. Kömür dışı açık işletmelerde makine-ekipman kaynaklı PM salınımlarının belirlenmesi üzerine literatürde çok az sayıda çalışmaya rastlanılmıştır. $\mathrm{Bu}$ nedenle Ülkemizdeki maden işletmelerinde her bir faaliyetten kaynaklanan PM salınımının ölçülmesine yönelik daha ayrıntılı çalışmalar yapılmalıdır. Böylece bu etkenin çalışanlar ve çevre üzerindeki etkileri daha iyi anlaşılabilir.

Sonuç olarak; madencilik faaliyetleri kaynaklı PM salınımı, yukarıda değinilen yaklaşımlar ile maden işletmesi projelendirme aşamasında iken tahmin edilebilir. Böylece işletmeler ile çevre yerleşim yerleri arasında oluşabilecek muhtemel şikâyet ve anlaşmazlıklar asgari düzeye indirilebilir.

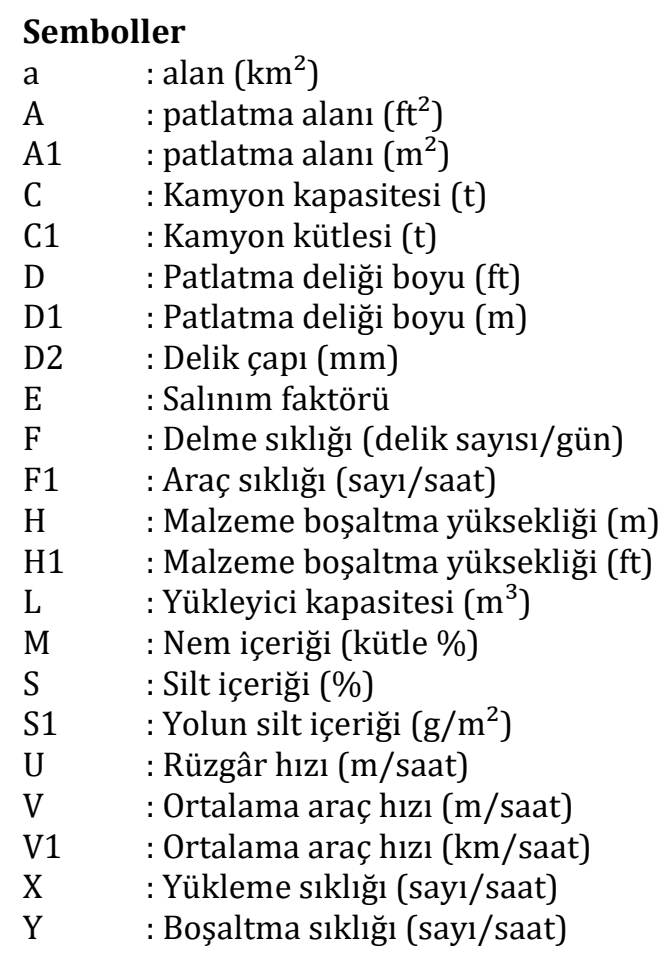

\section{Teşekkür}

$\mathrm{Bu}$ çalıșma, Sivas Cumhuriyet Üniversitesi Bilimsel Araştırma Projeleri (CÜBAP) Komisyonu tarafindan M780 Nolu proje kapsamında desteklenmiştir.

\section{Araştırmacıların Katkısı}

Zekeriya DURAN, literatürün araştırılması ve derlenmesinde; Bülent ERDEM düzenlenmesinde; Tuğba DOĞAN ise makale formatının hazırlanması konularında katkı sağlamışlardır.

\section{Çıkar Çatışması}

Yazarlar tarafından herhangi bir çıkar çatışması beyan edilmemiştir.

\section{Kaynaklar}

Air Pollution, (2020). Erişim adresi: https://www.who.int/health-topics/airpollution\#tab=tab 1

Appleton, T. J., Kingman, S. W., Lowndes, I. S. ve Silvester, S, A., (2006). The development of a modelling strategy for the simulation of fugitive dust emissions from in-pit quarrying activities: A UK case study, International Journal of Mining, Reclamation and Environment, Vol. 20 (1), 57-82. doi: https://doi.org/10.1080/13895260500396404 
Arregoce's, H. A., Rojano, R., Angulo, L. ve Restrepo, G., (2018). Intake fraction of $\mathrm{PM}_{10}$ from coal mine emissions in the North of Colombia, Journal of Environmental and Public Health, Volume, 8532463, 8. doi: https://doi.org/10.1155/2018/8532463

Axetell, K. ve Cowherd, C., (1984). Improved emission factors for fugitive dust from Western Surface Coal Mining Sources, US. Environmental Protection Agency, Cincinnati.

Badu, A., (2014). Dust monitoring, characterization and prediction in an opencast coal mining project, Department of Mining Engineering National Institute Of Technology Rourkela. Erişim adresi: http://ethesis.nitrkl.ac.in/6191/1/110MN062911.pdf

Balcl, S., (2016). Çimento üretiminde toz ve gürültü maruziyetinin değerlendirilmesi, Çalıșma ve Sosyal Güvenlik Bakanlığı İş Sağlığı ve Güvenliği Genel Müdürlüğü (Uzmanlık Tezi). Ankara.

Beloconi, A., Chrysoulakisc, N., Lyapustind, A., Jürg Utzinger, J. ve Vounatsou, P., (2018). Bayesian geostatistical modelling of $\mathrm{PM}_{10}$ and $\mathrm{PM}_{2.5}$ surface level concentrations in Europe using high-resolution satellite-derived products, Environment International, 121, 57-70. doi: https://doi.org/10.1016/j.envint.2018.08.041

Beșir, A. Ç., (2015). Yerüstü madenciliğinde kullanılan partikül madde emisyon faktörlerinin Türkiye ve uluslararası uygulamalarla değerlendirilmesi (Yüksek Lisans Tezi). Hacettepe Üniversitesi Fen Bilimleri Enstitüsü, Ankara.

Cao, J., Chow, C. J., Lee, S. C. F. ve Watson, G. J., (2013). Evolution of $\mathrm{PM}_{2.5}$ measurements and standards in the U.S. and future perspectives for China, Aerosol and Air Quality Research, 13, 1197-1211. doi: https://doi.org/10.4209/aaqr.2012.11.0302

CAFE, (2004). Second Position Paper on Particulate Matter, CAFE Working Group on Particulate Matter, 231. Erişim adresi: https://ec.europa.eu/environment/archives/cafe/p df/working groups/2nd position paper pm.pdf.

Catrambone, M., Canepari, S., Cerasa, M., Sargolini, T. ve Perrino, C., (2019). Performance Evaluation of a Very-low-volume Sampler for Atmospheric Particulate Matter, Aerosol and Air Quality Research, 19: 2160-2172. doi: https://doi: 10.4209/aaqr.2019.04.0195.

CCME (2020). Erişim adresi: https://www.ccme.ca/en/resources/air/pm ozone. $\underline{\mathrm{html}}$.

Chakraborty, M.K., Ahmad, M., Singh, R. S., Pal, D., Bandopadhyay, C. ve Chaulya, S. K., (2002). Determination of the emission rate from various opencast mines operations. Environ. Modell. Softw. 17 (5), 467-480. doi: https://doi.org/10.1016/S1364-8152(02)00010-5

Chaulya, S.K., (2006). Emission rate formulae for surface iron ore mining activities. Environmental Modeling Assessment, 11, 361-370. doi: https://doi.org/10.1007/s10666-005-9026-2

Choudhary M, P. ve Garg, V., (2013). Causes, Consequences and Control of Air Pollution, Conference: All India Seminar on Methodologies for Air Pollution Control At: Malviya National Institute of Technology, Jaipur, Rajasthan, India, 1-11. Erişim adresi:https://www.researchgate.net/publication/ 279202084 Causes Consequences and Control of Air Pollution

ÇEDB, (2004). Türkiye Çevre Atlası, ÇED ve Planlama Genel Müdürlüğü Cevre Envanteri Dairesi Başkanlığl, Ankara, $528 \mathrm{~s}$.

Çınar, İ., ve Şensöğüt, C., (2017). Mermer fabrikalarında toz koșullarının değerlendirilmesi, MCBÜ Soma Meslek Yüksekokulu Teknik Bilimler Dergisi, 1 (23), 40-48. Erişim adresi: https://dergipark.org.tr/tr/pub/somatbd/issue/30 $\underline{679 / 331470}$

ÇOB, (2008). Hava Kalitesi Değerlendirme ve Yönetimi Yönetmeliği, Çevre ve Orman Bakanlığı, Ankara.

ÇŞB, (2014). Sanayi Kaynaklı Hava Kirliliğinin Kontrolü Yönetmeliğinde Değișiklik Yapılmasına Dair Yönetmelik. Çevre ve Şehircilik Bakanlı̆̆ı, Ankara. Erişim adresi: https://www.resmigazete.gov.tr/eskiler/2020/11/ 20201106-2.htm

Dust (2020). Erişim adresi: https://manualzz.com/doc/28767715/environmen tal-monitoring-catalogue.

EC (2020). Erişim adresi: https://ec.europa.eu/environment/air/quality/sta ndards.htm.

Erol, İ., (2012). Türkiye Taşkömürü Kurumu ocaklarında solunabilir toz içindeki kül ve kuvars miktarlarının sistematik olarak ölçülmesi ve istatistiksel değerlendirilmesi (Doktora Tezi), Zonguldak Karaelmas Üniversitesi Fen Bilimleri Enstitüsü, Zonguldak.

Evyapan, F., Mungan, D., Akgün, M., ve Arbak, P., (2012). Hava kalitesi ve sağlık, T.C. Sağlık Bakanlığı ve Türk Toraks Derneği, Ankara, 14-16.

Gao, M., Beig, G., Song, S., Zhang, H., Hu, J., Ying, Q., ... McElroy, M.B., (2018). The impact of power generation emissions on ambient $\mathrm{PM}_{2.5}$ pollution and human health in China and India, Sustainable Cities 
and Society, 42, 259-275. doi: https://doi:10.1016/j.envint.2018.09.015

Gautam, S., Patra, A.K., Sahu, S.P. ve Hitch, M., (2016). Particulate matter pollution in opencast coal mining areas: a threat to human health and environment, International Journal of Mining, Reclamation and Environment, 32 (2), 75-92. doi: https://doi.org/10.1080/17480930.2016.1218110

Ghose, M.K., (2004). Emission factors for the quantification of dust in India coal mines, Journal of Scientific and Industrial Research 63, 763-768. Erişim adresi:

http://nopr.niscair.res.in/handle/123456789/550 $\underline{0}$

Ghose, M.K. ve Majee, S. R., (2007). Characteristics of Hazardous Airborne Dust around an Indian Surface Coal Mining Area, Environ Monit Assess, 130: 17-25. doi: https://doi.org/10.1007/s10661-006-9448-6

Health Effects, (2020). Health and Environmental Effects of Particulate Matter (PM). Erişim adresi: https://www.epa.gov/pm-pollution/health-andenvironmental-effects-particulate-matter-pm

Hendryx, M., (2015). The public health impacts of surface coal mining, The Extractive Industries and Society, 2, 820-826. doi: https://doi.org/10.1016/j.exis.2015.08.006

Huertas, J. I., Camacho, D. A. ve Huertas M. E., (2012). Standardized emissions inventory methodology for open-pit mining areas, Environ Sci Pollut Res, 19: 2784-2794. doi: https://doi.org/10.1007/s11356$\underline{012-0778-3}$

Kim, K., Kabir, E. ve Kabir, S., (2015). A review on the human health impact of airborne particulate matter, Environment International 74, 136-143. doi: https://doi.org/10.1016/j.envint.2014.10.005

Lal, B. ve Tripathy, S.S., (2012). Prediction of dust concentration in open cast coal mine using artificial neural network. Atmos. Pollut. Res. 3, 211-218. doi: https://doi.org/10.5094/APR.2012.023

Laney, A.S. ve Weissman, D.N., (2014). Respiratory diseases caused by coal mine dust, J Occup. Environ. Med., 56 (10), 1-13. doi: https://doi.org/10.1097/JOM.0000000000000260

Lashgari, A. ve Kecojevic, V., (2016). Comparative analysis of dust emission of digging and loading equipment in surface coal mining, International Journal of Mining, Reclamation and Environment, 30 (3). 181-196, doi: https://doi.org/10.1080/17480930.2015.1028516

Liu, B.Y.H., Whitby, K.T. ve Pui, D.Y.H. (1974). A Portable electrical analyzer for size distribution measurement of submicron aerosols, Journal of the Air Pollution
Control Association 24, 1067-1072. doi: https://doi.org/10.1080/00022470.1974.1047001 $\underline{6}$

Martin, F., Pujadas, M., Artinano, B., Gomez-Moreno, F., Palomino, I., Moreno, N., ... Guerra, A., (2007). Estimates of atmospheric particle emissions from bulk handling of dusty materials in Spanish Harbours, Atmospheric Environment, 41, 6356-6365. doi: https://doi.org/10.1016/j.atmosenv.2006.12.003

Martins, N.R. ve Carrilho da Graça, G., (2018). Impact of $\mathrm{PM}_{2.5}$ in indoor urban environments: A review, Sustainable Cities and Society 42, 259-275. doi: https://doi.org/10.1016/j.scs.2018.07.011

Miçooğulları, A., (2018). Hatay Kuruyer mevkiindeki taş ocaklarında iş güvenliği açısından taş tozu riskinin araştırılması (Yüksek lisans tezi), Çukurova Üniversitesi Fen Bilimleri Enstitüsü, Adana.

Miller, L. ve Xu, X., (2018). Ambient PM2.5 human health effects-findings in China and research directions, Atmosphere, 9 (424), 2-16. doi: https://doi.org/10.3390/atmos9110424

NAAQS (2020). NAAQS Table, Erişim adresi: https://www.epa.gov/criteria-airpollutants/naaqs-table

Nagesha, K.V., Sastry V.R. ve Ram, C. K., (2016). Prediction of dust dispersion during drilling operation in open cast coal mines: A multi regression model, International Journal of Environmental Sciences, 6 (5), 681-696. doi: https://doi.org/10.6088/ijes.6064

NPI, (2001). (National Pollution Inventory), Emission Estimation Technique Manual for Mining Version 2.3, Australian Government, Canberra. Erişim adresi: https://cwm.unitar.org/publications/publications/ $\mathrm{cbl} / \mathrm{prtr} / \mathrm{pdf} / \mathrm{cat}$ /Australia_mining.pdf

NPI, (2012). (National Pollution Inventory), Emission Estimation Technique Manual for Mining Version 3.1, Australian Government, Canberra. Erişim adresi: http://www.npi.gov.au/resource/emissionestimation-technique-manual-mining

NSW, (2020). Consultation paper clean air for NSW, Erişim adresi: https://www.epa.nsw.gov.au/Lmedia/epa/corporate-site/resources/air/cleanair-nsw 160415.pdf

NSW EPA, (2015). NSW Coal Mining Benchmarking Study Best Practice Measures for Reducing Non-Road Diesel Exhaust Emissions, Final Report, NSW Environment Protection Authority (EPA) 59-61 Goulburn Street, Sydney PO Box A290 Sydney South NSW 1232, ISBN 978-1-74359-970-9, 260 p. Erişim adresi: https://www.epa.nsw.gov.au/- 
/media/epa/corporate-site/resources/air/150242coal-mine-study.pdf

Önder, M., ve Yiğit, E., (2009). Assessment of respirable dust exposures in an opencast coal mine, Environ. Monit Assess. 152: 393-401. doi: https://doi.org/10.1007/s10661-008-0324-4

Öztürk, N., (2016). Açık işletmelerde ağır iş makinesi operatörlerinin gürültü, titreşim ve toz maruziyetlerinin değerlendirilmesi (Uzmanlık tezi), Çalışma ve Sosyal Güvenlik Bakanlığı İş Sağlığı ve Güvenliği Genel Müdürlüğü, Ankara.

Pandey, B., Agrawal, M. ve Singh S., (2014). Assessment of air pollution around coal mining area: Emphasizing on spatial distributions, seasonal variations and heavy metals, using cluster and principal component analysis, Atmospheric Pollution Research, 5, 79-86. doi: https://doi.org/10.5094/APR.2014.010

Papagiannis, A., Roussos, D., Menegaki, M. ve Damigos, D., (2014). Externalities from lignite mining-related dust emissions, Energy Policy 74, 414-424. doi: https://doi.org/10.1016/j.enpol.2014.08.026

Patra, A. K., Gautam, S. ve Kumar, P., (2016). Emissions and human health impact of particulate matter from surface mining operation - A review, Environmental Technology \& Innovation, 5, 233-249. doi: https://doi.org/10.1016/j.eti.2016.04.002

Particulate Matter (PM) Basics, (2020). Erişim adresi: https://www.epa.gov/pm-pollution/particulatematter-pm-basics\#PM

Perrino, C., (2010). Atmospherıc Partıculate Matter, Proceedings of a C.I.S.B. Minisymposium, 35-43. Erişim adresi: https://www.researchgate.net/profile/CinziaPerrino/publication/228652246 Atmospheric part iculate matter/links/0fcfd511a53bfb95fe000000/A tmospheric-particulate-matter.pdf

Petavratzi, E., Kingman, S. ve Lowndes, I., (2005). Particulates from mining operations: A review of sources, effects and regulations, Minerals Engineering, 18, 1183-1199. doi: https://doi.org/10.1016/j.mineng.2005.06.017

Pilling, M., ApSimon, H., Carruthers, D., Carslaw, D., Colvile, R., Derwent, D., ... Stedman, J., (2005). Particulate Matter in the United Kingdom, Department for the Environment, Food and Rural Affairs Nobel House 17 Smith Square, London, Product code PB10580 ISBN 0-85521-143-1, 444.

Rahul, J. ve Jain, M.K., (2014). An Investigation in to the Impact of Particulate Matter on Vegetation along the National Highway: A Review, Research Journal of Environmental Sciences 7, 356-372. doi: https://doi.org/10.3923/rjes.2014.356.372
Ren, L., Yang, W. ve Bai, Z., (2017). Characteristics of major air pollutants in China, Ambient air pollution and health impact in China, 9. doi: https://doi.org/10.1007/978-981-10-5657-4 2

Richardson, C., Rutherford, S. ve Agranovski E. I., (2019). Open cut black coal mining: Empirical verification of PM2.5 air emission estimation techniques, Atmospheric Research, 216, 151-159. doi: https://doi.org/10.1016/i.atmosres.2018.10.008

Rodriguez, S., Querol, X., Alastuey, A. ve De la Rosa, J., (2007). Atmospheric particulate matter and air quality in the Mediterranean: A review, Environ Chem Lett, 1-7. doi: https://doi.org/10.1007/s10311-006-0071-0

Silvester, S. A., Lowndes, I. S. ve Hargreaves, D. M., (2009). A computational study of particulate emissions from an open pit quarry under neutral atmospheric conditions, Atmospheric Environment 43, 6415-6424. doi: https://doi.org/10.1016/j.atmosenv.2009.07.006

SIMRAC, (2003). Handbook to reduce the exposure of workers to dust, Members of the Special Interest Group on Dust and Ventilation, Safety in Mines Research Advisory Committee (SIMRAC), South Africa, COL 027.

Singh, G., Pal, A. ve Khoiyanbam, R.S., (2009). Impact of mining on human health in and around Jhansi, Bundelkhand region of Uttar Pradesh, India, Journal of Ecophysiology and Occupational Health, 9, 47-54. Erişim adresi: https://www.researchgate.net/publication/289196 $\underline{567}$

Şahin, A. Ü., (2012). İstanbul üniversitesi Avcılar Yerleşkesi'nde solunabilir partikül maddenin boyut dağılımının ve element içeriğinin incelenmesi (Yüksek lisans tezi). İstanbul Üniversitesi Fen Bilimleri Enstitüsü, İstanbul.

THHP, (2019). Temiz Hava Hakkı Platformu, Hava Kirliliği ve Sağlık Etkileri Kara Rapor, 70.

Tripathy, D. P., Dash, T, R., Badu, A. ve Kanungo, R., (2015). Assessment and modelling of dust concentration in an opencast coal mine in India, Global Nest Journal, 17 (4), 825-834. doi: https://doi.org/10.30955/gnj.001611

Tripathy, D. P. ve Dash, T, R., (2019). Measurement of respirable dust concentration and assessment of health risk due to metals around an opencast coal mine of Talcher, Odisha, GEOFIZIKA, 36 (1), 77-106. doi: https://doi.org/10.15233/gfz.2019.36.2

Tsiouri, V., Kakosimos, K. ve Kumar, P., (2015). Concentrations, physicochemical characteristics and exposure risks associated with particulate matter in the Middle East Area-A review, Air Qual. Atmos. 
Health 8, 67-80. doi: https://doi.org/10.1007/s11869-014-0277-4

USEPA, (1988). Supplement B to Compilation of Air Pollutant Emissions Factors, Volume I: Stationary Point and Area Sources, U.S. Environmental Protection Agency, Office of Air Quality Planning and Standards, Research Triangle Park, North Carolina, 188 .

USEPA, (1991). Review of Surface Coal Mining Emissions Factors. U.S. Environmental Protection Agency, Office of Air Quality Planning and Standards, Research Triangle Park, North Carolina, 144.

USEPA, (1995). (United States Environmental Protection Agency), AP-42 Compilation of Air Pollutant Emission Factors, Introduction, North Carolina.

USEPA, (1998). Revision of emission factors for AP-42 Section 11.9 Western surface coal mining. Revised final report, MRI Project No. 4604-02; Emission Factor and Inventory Group, Office of Air Quality Planning and Standards, US Environmental Protection Agency.

USEPA, (2006a). Revision of Emission Factors for AP-42. Chapter 13: Miscellaneous Source. Section 13.2.2: Unpaved Roads (Fugitive Dust Sources), 20.

USEPA, (2006b). Revision of Emission Factors for AP-42. Chapter 13: Miscellaneous Source. Section 13.2.4: Aggregate Handling and Storage Piles, 6.

Vidinli, N., Özkan, E, K., Topçu, D., Yamurluklu, Y., Gedikli, F, G., ve Kürkçü, E, A., (2016). Cimento sektöründe tozla mücadele rehberi, Çalışma ve Sosyal Güvenlik Bakanlığı İş Sağlı̆̆ı ve Güvenliği Genel Müdürlüğü, Bakanlık: 57, Ankara.

Whitby, K.T., Husar, R.B. ve Liu, B.Y.H. (1972). The aerosol size distribution of Los Angeles Smog. Journal of Colloid and Interface Science, 39, 177-204. doi: https://doi.org/10.1016/00219797(72)90153-1

WHO, (1999). Hazard prevention and control in the work environment: Airborne dust. Erişim adresi: https://www.who.int/occupational health/publicat ions/en/oehairbornedust3.pdf

WHO, (2006). Health risks of particulate matter from long-range transboundary air pollution, WHO Regional Office for Europe Scherfigsvej 8 DK-2100 Copenhagen $\varnothing$, Denmark, E88189, 113. Erişim adresi: $\quad$ https://www.euro.who.int/data/ assets/pdf file/0006/78657/E88189.pdf

Xing, Y-F., Xu, Y-H., Shi, M-H. ve Lian, Y-X., (2016). The impact of $\mathrm{PM}_{2.5}$ on the human respiratory system, Journal of Thoracic Disease, 8(1), E69-E74. doi: https://doi.org/10.3978/j.issn.2072$\underline{1439.2016 .01 .19}$
Zhang, X., Chen, W., Ma, C. ve Zhan, S., (2013). Modeling particulate matter emissions during mineral loading process under weak wind simulation, Science of the Total Environment 449, 168-173. doi: https://doi.org/10.1016/i.scitotenv.2013.01.050 
EK 1

Açık Maden İșletmelerinde PM Salınım Tahmin Formülleri

\begin{tabular}{|c|c|c|c|c|c|}
\hline Faaliyetler/Yazar & Birim & $\begin{array}{l}\text { Emisyon tahmin formülü/faktörü } \\
\text { PM }_{15}\end{array}$ & $\mathbf{P M}_{10}$ & $\mathbf{P M}_{2,5}$ & Birim \\
\hline \multicolumn{6}{|c|}{ ( } \\
\hline Axetell ve Cowherd 1984 & \multirow{5}{*}{$\begin{array}{l}\text { Kömür } \\
\text { (dekapaj) }\end{array}$} & 1,3 & & & $\mathrm{lb} /$ delik \\
\hline $\begin{array}{l}\text { Chakraborty ve diğ., } 2002 \text {; } \\
\text { Lal ve Tripathy, } 2012\end{array}$ & & $\begin{array}{l}E=0,0325 *[\{(100-M) * S * U\} /\{(100-S) * M\}]^{0,1} * \\
\left(D_{2} * F\right)^{0,3}\end{array}$ & & & $\mathrm{~g} / \mathrm{s}$ \\
\hline USEPA, 1998 & & 0,59 (üst örtü), 0,1 (kömür) & & & $\mathrm{kg} /$ delik \\
\hline NPI, 2012 & & 0,59 & 0,31 & & $\mathrm{~kg} /$ delik \\
\hline Nagesha ve diğ., 2016 & & $E=0,499-0,037 * M+0,015 * S$ & & & $\mathrm{~g} / \mathrm{s}$ \\
\hline \multicolumn{6}{|l|}{ Patlatma } \\
\hline $\begin{array}{l}\text { Axetell ve Cowherd 1984; USEPA, } \\
1998\end{array}$ & \multirow{4}{*}{$\begin{array}{l}\text { Kömür } \\
\text { (dekapaj) }\end{array}$} & $E=2550 * A^{0,6} * D^{-1,5} * M^{-2,3}$ & & $\mathrm{TAPM}^{*} 0,03$ & lb/pat. \\
\hline $\begin{array}{l}\text { USEPA, 1991; USEPA, 1995; NPI, } \\
\text { 2001; NPI, } 2012\end{array}$ & & $E=0,00022 * A_{1}^{1,5}$ & TAPM $* 0,52$ & & $\mathrm{~kg} /$ pat. \\
\hline USEPA, 1998 & & $E=0,000014 * A^{1,5}$ & $\mathrm{TAPM}^{*} 0,52$ & $\mathrm{TAPM}^{*} 0,03$ & $\mathrm{lb} /$ pat. \\
\hline NPI, 2001; 2012 & & $E=344 * A_{1}^{0,8} * D_{1}^{-1,8} * M^{-1,9}$ & TAPM $^{*} 0,52$ & & $\mathrm{~kg} /$ pat. \\
\hline \multicolumn{6}{|l|}{ Yükleme } \\
\hline $\begin{array}{l}\text { Chakraborty ve diğ., 2002; } \\
\text { Lal ve Tripathy, } 2012\end{array}$ & \multirow{2}{*}{$\begin{array}{l}\text { Kömür } \\
\text { (dekapaj) }\end{array}$} & $\begin{array}{l}E=\left[0,018 *\{(100-M) / M\}^{1,4} *\left\{S /(100-S)^{0,4}\right\} *(U *\right. \\
\left.H * X * L)^{0,1}\right]\end{array}$ & & & $\mathrm{g} / \mathrm{s}$ \\
\hline NPI, 2012 & & $E=0,74 * 0,0016 *(U / 2,2)^{1,3} *(M / 2,0)^{-1,4}$ & $\begin{array}{l}E=0,35 * 0,0016 * \\
(U / 2,2)^{1,3} *(M / 2,0)^{-1,4}\end{array}$ & & $\mathrm{~kg} / \mathrm{ton}$ \\
\hline Chaulya, 2006 & $\begin{array}{l}\text { Demir } \\
\text { (pasa) }\end{array}$ & $\begin{array}{l}E=\left[0,0081 *\{(100-M) / M\}^{1,4} *\left\{S /(100-S)^{0,3}\right\} *\right. \\
\left.U^{1,1} *(H * X * L)^{0,1}\right]\end{array}$ & & & $\mathrm{g} / \mathrm{s}$ \\
\hline USEPA, 2006b & Agrega & $E=0,74 * 0,0016 *(U / 2,2)^{1,3} *(M / 2,0)^{-1,4}$ & $E=(0,35 / 0,74) * T A P M$ & $E=0,07 * T A P M$ & $\mathrm{~kg} / \mathrm{ton}$ \\
\hline \multicolumn{6}{|l|}{ Yükleme } \\
\hline $\begin{array}{l}\text { Axetell ve Cowherd 1984; USEPA, } \\
1998\end{array}$ & \multirow{4}{*}{$\begin{array}{l}\text { Kömür } \\
\text { (üretim) }\end{array}$} & $E=0,119 * M^{-0,9}$ & & TAPM $^{*} 0,019$ & $\mathrm{lb} /$ ton \\
\hline $\begin{array}{l}\text { USEPA, 1991; } \\
\text { USEPA, 1995 }\end{array}$ & & $E=0,0596 * M^{-0,9}$ & $\mathrm{PM}_{15} * 0,75$ & TAPM $^{*} 0,019$ & $\mathrm{~kg} / \mathrm{ton}$ \\
\hline $\begin{array}{l}\text { Chakraborty ve di } \breve{g}_{.,} 2002 \text {; } \\
\text { Lal ve Tripathy, } 2012\end{array}$ & & $\begin{array}{l}E=\left[\{(100-M) / M\}^{0,1} *\{S /(100-S)\}^{0,3} * H^{0,2} *\right. \\
\{U /(0,2+1,05 * U)\} *\{X * L /(15,4+0,87 * X * L)\}]\end{array}$ & & & $\mathrm{g} / \mathrm{s}$ \\
\hline NPI, 2012 & & $E=0,580 * M^{-1,2}$ & $E=0,0447 * M^{-0,9}$ & & $\mathrm{~kg} / \mathrm{ton}$ \\
\hline Chaulya, 2006 & $\begin{array}{l}\text { Demir } \\
\text { (cevher) }\end{array}$ & $\begin{array}{c}E=\left[H *\{(100-M) / M\}^{0,4} *\{0,555 * S /(100-S)\}\right. \\
\left.*\left(U^{2} * X * L\right)^{0,1}\right]\end{array}$ & & & $\mathrm{g} / \mathrm{s}$ \\
\hline \multicolumn{6}{|l|}{ Küreme (dozer) } \\
\hline $\begin{array}{l}\text { USEPA, 1988; } \\
\text { USEPA, 1991 }\end{array}$ & \multirow{4}{*}{ Kömür } & $E=8,44 * S^{1,5} * M^{-1,4}$ & $\mathrm{PM}_{15} * 0,75$ & TAPM $^{*} 0,022$ & $\mathrm{~kg} / \mathrm{saat}$ \\
\hline USEPA, 1995 & & $E=35,6 * S^{1,2} * M^{-1,4}$ & $\mathrm{PM}_{15} * 0,75$ & $\mathrm{TAPM}^{*} 0,022$ & $\mathrm{~kg} / \mathrm{saat}$ \\
\hline USEPA, 1998 & & $E=78,4 * S^{1,2} * M^{-1,3}$ & & TAPM $^{*} 0,022$ & $\mathrm{lb} /$ saat \\
\hline NPI, 2001; 2012 & & $E=35,6 * S^{1,2} * M^{-1,4}$ & $E=6,33 * S^{1,5} * M^{-1,4}$ & & $\mathrm{~kg} / \mathrm{saat}$ \\
\hline
\end{tabular}


Açık Maden İșletmelerinde PM Salınım Tahmin Formülleri (devam ediyor)

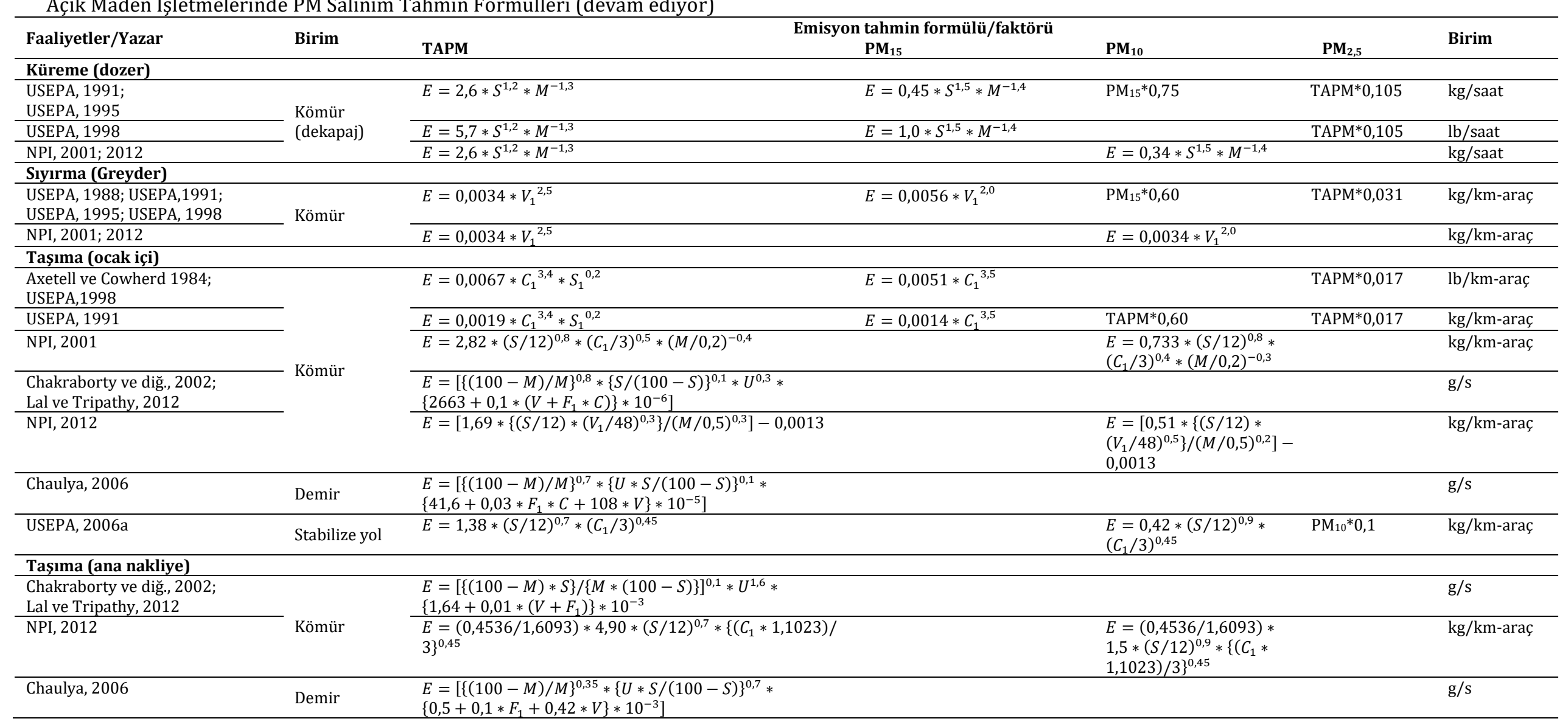


Açık Maden İșletmelerinde PM Salınım Tahmin Formülleri (devam ediyor)

\begin{tabular}{|c|c|c|c|c|c|c|}
\hline Faaliyetler/Yazar & Birim & TAPM & $\begin{array}{l}\text { tahmin formülü/faktörü } \\
\text { PM }_{15}\end{array}$ & $\mathbf{P M}_{10}$ & $\mathbf{P M}_{2,5}$ & Birim \\
\hline \multicolumn{7}{|l|}{ Boşaltma } \\
\hline $\begin{array}{l}\text { Chakraborty ve diğ., } 2002 \text {; } \\
\text { Lal ve Tripathy, } 2012\end{array}$ & $\begin{array}{l}\text { Kömür } \\
\text { (dekapaj) }\end{array}$ & $\begin{array}{l}E=\left[1,76 * H^{0,5} *\{(100-M) / M\}^{0,2} *\{S /(100-S)\}^{2} *\right. \\
\left.U^{0,8} *(C * Y)^{0,1}\right]\end{array}$ & & & & $\mathrm{g} / \mathrm{s}$ \\
\hline Chaulya, 2006 & $\begin{array}{l}\text { Demir } \\
\text { (pasa) }\end{array}$ & $\begin{array}{l}E=\left[0,33 *\{U * H(100-M) / M\}^{0,1} *\{S /(100-S)\}^{0,3} *\right. \\
\left.(C * Y)^{0,15}\right]\end{array}$ & & & & $\mathrm{g} / \mathrm{s}$ \\
\hline USEPA, 2006b & Agrega & $E=0,74 * 0,0016 *(U / 2,2)^{1,3} *(M / 2,0)^{-1,4}$ & $E=(0,48 / 0,74) * T A P M$ & $E=(0,35 / 0,74) * T A P M$ & $E=0,07 * T A P M$ & $\mathrm{~kg} / \mathrm{ton}$ \\
\hline \multicolumn{7}{|l|}{ Boșaltma } \\
\hline $\begin{array}{l}\text { Chakraborty ve diğ., } 2002 \text {; } \\
\text { Lal ve Tripathy, } 2012\end{array}$ & \multirow{2}{*}{$\begin{array}{l}\text { Kömür } \\
\text { (üretim) }\end{array}$} & $\begin{array}{c}E=0,023 *[\{(100-M) * S * H\} /\{M *(100-S)\}]^{2} \\
*\left(U^{3} * C * Y\right)^{0,1}\end{array}$ & & & & $\mathrm{~g} / \mathrm{s}$ \\
\hline NPI, 2012 & & $E=0,74 * 0,0016 *(U / 2,2)^{1,3} *(M / 2,0)^{-1,4}$ & & $\begin{array}{l}E=0,35 * 0,0016 * \\
(U / 2,2)^{1,3} *(M / 2,0)^{-1,4}\end{array}$ & & $\mathrm{~kg} / \mathrm{ton}$ \\
\hline Chaulya, 2006 & Demir & $\begin{array}{l}E=0,156 * H^{0,6} * \\
{[\{(100-M) * S * U * L * X\} /\{M *(100-S)\}]^{0,1}}\end{array}$ & & & & $\mathrm{~g} / \mathrm{s}$ \\
\hline \multicolumn{7}{|l|}{ Dekapaj sahası } \\
\hline $\begin{array}{l}\text { Chakraborty ve diğ., } 2002 \text {; } \\
\text { Lal ve Tripathy, } 2012\end{array}$ & Kömür & $\begin{array}{l}E=\left[\{(100-M) / M\}^{0,2} *\{S /(100-S)\}^{0,1} *\right. \\
\{U /(2,6+120 * U)\} *\{a /(0,2+276,5 * a)\}]\end{array}$ & & & & $\mathrm{g} / \mathrm{s}$ \\
\hline Chaulya, 2006 & Demir & $\begin{array}{l}E=\left[\{(100-M) / M\}^{0,1} *\{S /(100-S)\}^{0,6} *\right. \\
\{U /(19+0,01 * U)\} *\{a /(6+256 * a)\}]\end{array}$ & & & & $\mathrm{g} / \mathrm{s}$ \\
\hline \multicolumn{7}{|l|}{ Stok sahası } \\
\hline Chakraborty ve diğ., 2002 & Kömür & $\begin{array}{l}E=\{(100-M) / M\}^{0,1} *\{S /(100-S)\} * \\
\{U /(71+43 * U)\} *[\{C * Y /(329+7,6 * C * Y)\}+ \\
\{L * X /(30+900 * X * L)\}]\end{array}$ & & & & $\mathrm{g} / \mathrm{s}$ \\
\hline Chaulya, 2006 & Demir & $\begin{array}{l}E=\{U *(100-M) / M\}^{0,2} *\{S /(100-S)\}^{3,7} * \\
{[\{(C * Y) /(76,7+14,5 * C * Y)\}+} \\
\{(L * X) /(6,7+3,3 * X * L)\}]\end{array}$ & & & & $\mathrm{g} / \mathrm{s}$ \\
\hline \multicolumn{7}{|l|}{ Çekmekepçe çalışması } \\
\hline USEPA, 1988 & \multirow{4}{*}{$\begin{array}{l}\text { Kömür } \\
\text { (dekapaj) }\end{array}$} & $E=0,0034 * H_{1}{ }^{1,1} * M^{-0,3}$ & $E=0,0034 * H_{1}^{0,7} * M^{-0,3}$ & $\mathrm{PM}_{15}{ }^{*} 0,75$ & TAPM $^{*} 0,017$ & $\mathrm{lb} / \mathrm{yd}^{3}$ \\
\hline USEPA, 1991; USEPA, 1995 & & $E=0,0046 * H^{1,1} * M^{-0,3}$ & $E=0,0029 * H^{0,7} * M^{-0,3}$ & $\mathrm{PM}_{15} * 0,75$ & TAPM $^{*} 0,017$ & $\mathrm{~kg} / \mathrm{m}^{3}$ \\
\hline USEPA, 1998 & & $E=0,0021 * H_{1}^{1,1} * M^{-0,3}$ & $E=0,0021 * H_{1}^{0,7} * M^{-0,3}$ & $\mathrm{PM}_{15} * 0,75$ & $\mathrm{TAPM}^{*} 0,017$ & $\mathrm{lb} / \mathrm{yd}^{3}$ \\
\hline NPI, 2001; 2012 & & $E=0,0046 * H^{1,1} * M^{-0,3}$ & & $E=0,0022 * H^{0,7} * M^{-0,3}$ & & $\mathrm{~kg} / \mathrm{m}^{3}$ \\
\hline
\end{tabular}

